Yayın Geliş Tarihi: 23.03.2020

Yayına Kabul Tarihi: 07.05.2021

Online Yayın Tarihi: 30.06.2021

http://dx.doi.org/10.16953/deusosbil.708201
Dokuz Eylül Üniversitesi

Sosyal Bilimler Enstitüsü Dergisi

Cilt: 23, Say1: 2, Y11: 2021, Sayfa: 925-956

ISSN: 1302-3284 E-ISSN: 1308-0911

Araştırma Makalesi

\title{
BÖLGESEL KALKINMA ÇALIŞMALARINDA GELENEKSEL VE TAMAMLAYICI TIP SEKTÖRÜNÜN (GETAT) ROLÜ: Düzce İli GETAT Sektörünün Uluslararası Rekabetçilik Analizi Çalışmasıı ${ }^{1}$
}

\author{
Serhat FIRAT \\ Ismail Hakkı ERASLAN ${ }^{* *}$
}

$\ddot{O}_{z}$

Dünyanın çeşitli bölgelerinde GETAT sektörünün bölge kalkınmasını sağlayacak güce (çekirdek yeteneğe) sahip olması ilgili kurumları, sektörün geliştirilmesi yönünde harekete geçirmiş ve birçok çalışma (akademik ve sektörel gelişim) başlatılmasına vesile olmuştur. Bu bağlamda, Düzce ili GETAT sektörünün uluslararası rekabetçilik gücü düzeyini ortaya çıkarmak ve bölge kalkınması açısından önemini vurgulamak bu çalışmanın temel amacını oluşturmaktadır. Sektörün geliştirilmesine yönelik temel stratejilerin ve modellerin belirlenmesi de hedeflenmektedir. Ayrica sektörün bölgesel ekonomik kalkınmada kaldıraç etkisi yaratacak etkisi de araştırılmıştır.

Araştırmanın amacı doğrultusunda nitel ve nicel araştırma yaklaşımlarına bă̆lı olarak, birincil ve ikincil veri toplama tekniklerine müracaat edilmiş olup, (1) yüz yüze anket, (2) yarı yapılandırılmış derinlemesine mülakat ve (3) uzman görüşü teknikleri kullanılarak veriler elde edilmiştir. Verilerinin analizi aşamasında, içerik analizi (tematik kodlama) ve betimsel analiz yöntemleri kullanılmıştır. Aynı zamanda araştırma analizleri Elmas Model çerçevesinde değerlendirilmiş ve yorumlanmıştır. Araştırma analizleri bulgularına göre; Düzce ili GETAT sektörünün uluslararası rekabetçilik gücünün düşük

\footnotetext{
${ }^{1}$ Bu makale Mayıs 2019 tarihinde Prof. Dr. İsmail Hakkı ERASLAN danışmanlığında Düzce Üniversitesi Sosyal Bilimler Enstitüsü Sağlık Yönetimi Anabilim Dalında yazılmış olan DÜZCE İLININ GELENEKSEL VE TAMAMLAYICI TIP (GETAT) SEKTÖRÜNÜN ULUSLARARASI REKABETÇILİK ANALIZİ adlı tezden türetilmiştir.

Bu makale için önerilen kaynak gösterimi (APA 6. Sürüm):

Fırat, S., Eraslan, İ. H., (2021). Bölgesel kalkınma çalışmalarında geleneksel ve tamamlayıcı tıp sektörünün (GETAT) rolü: Düzce ili GETAT sektörünün uluslararası rekabetçilik analizi çalışması. Dokuz Eylül Üniversitesi Sosyal Bilimler Enstitüsü Dergisi, 23 (2), 925-956.

* Öğr. Gör., Hakkari Üniversitesi, Sağlık Hizmetleri Meslek Yüksek Okulu, Yönetim Organizasyon Bölümü, ORCID: 0000-0003-3934-2932, serhatfirat@ hakkari.edu.tr.

** Prof. Dr., Düzce Üniversitesi, İşletme Fakültesi, Sağlık Yönetimi Bölümü., ORCID: 00000002-2108-0279, hakkieraslan@ duzce.edu.tr.
} 
düzeyde olduğu tespit edilmiştir. Ancak sektörün önemli bir potansiyel taşıldı̆̆ bulguları da ortaya çıkarılmıştır.

Aynı zamanda GETAT sektörünün uluslararası rekabetçilik gücünü artıracak 5 farklı ana eksen çerçevesinde 29 farkl alt değişkene yönelik sektörel stratejik gelişme önerileri de ortaya çıkarılmıştır.

Bu bă̆lamda modelde yer alan değişkenlere bă̆ll olarak, tüm alt değişkenlerin detaylı analizlerinin yapılıp rekabetçilik güçlerinin arttırılmasına yönelik kümelenme temelli programlar ile desteklenmesi öngörülmektedir.

Anahtar Kelimeler: Bölgesel Kalkınma, Ekonomik Kalkınma, Uluslararası Rekabetçilik, Geleneksel Tip, Alternatif Tip.

\title{
THE ROLE OF TRADITIONAL AND COMPLEMENTARY MEDICINE SECTOR FOR REGIONAL DEVELOPMENT \\ Study of Competitiveness Analysis of the Traditional and Complementary Medicine (TCM) Sector of Düzce Province ${ }^{2}$
}

\begin{abstract}
The fact that the traditional and complementary medicine (TCM) sector has the power (core capability) for regional development in various regions of the world has mobilized the relevant institutions for the development of the sector and led to the initiation of many studies (academic and sectoral development). In this context, revealing the international competitiveness level of the TCM sector in Düzce province is the main aim of this study. It is also aimed to identify basic strategies and models for the development of the sector. In addition, the effect of the sector that will create leverage effect on regional economic development has been investigated.

In accordance with the qualitative and quantitative research approaches, primary and secondary data collection techniques were applied in order to reach the aim of the research. In this context; Data were obtained using (1) face to face questionnaire, (2) semistructured in-depth interview and (3) expert opinion techniques. In the analysis of research data, content analysis (thematic coding) and descriptive analysis methods were used. At the same time, research analyzes were evaluated and interpreted within the framework of the Diamond Model. According to the research analysis findings; It has been determined that the international competitiveness of the TCM sector in Düzce is low. However, it was also found that the sector has a significant potential.

Strategic development proposals for 29 different sub-variables have been developed within the framework of 5 different main axes that will increase the international competitiveness of the TCM sector. In this context, depending on the variables in the model,

\footnotetext{
${ }^{2}$ This article is derived from the thesis entitled INTERNATIONAL COMPETITIVENESS ANALYSIS OF THE TRADITIONAL AND COMPLEMENTARY MEDICINE (TCM) Phd. İsmail Hakkı ERASLAN, in Düzce University Social Sciences Institute, Department of Health Management.
} SECTOR of DÜZCE PROVINCIAL, which was written in May 2019 under the consultancy of
\end{abstract}


it is envisaged that detailed analysis of all sub-variables will be conducted and supported by cluster-based programs to increase their competitiveness.

Keywords: Regional Development, Economic Development, International Competitiveness, Traditional Medicine, Alternative Medicine.

\section{GİRIŞ}

Kalkınma, dinamik bir yapı olup mevcut konumdaki düzeyden daha iyi bir düzeye yükselmek için yapılan faaliyetler sonucunda bir ulusun yapısal niteliklerinin pozitif değişkenlik göstermesidir. Kalkınma, ekonomik kalkınma, çevresel kalkınma, fiziksel kalkınma ve sosyal kalkınma olmak üzere toplamda 4 temel eksen üzerinde gerçekleştirilmektedir. Bu temel eksenler üzerinden kalkınma sağlanırken çalışmalar eş zamanlı olarak yürütülmektedir (Tolunay ve Akyol, 2006, s. 116). İşaret edilen temel eksenler çerçevesinde gerçekleştirilecek olan kalkınma olgusunda insan kavramı yani insani kalkınma her bir eksenin merkezinde yer almaktadır (Yüksel ve Eraslan, 2015). Bu çalışmada da herhangi bir sektörün çekirdek yeteneğinin ortaya çıkarılması ile kalkınmanın, özellikle de ekonomik kalkınmanın sağlanıp sağlanamayacağı analiz edilerek sektörel rekabet gücü düzeyi ortaya çıkarılmıştır. Nitekim Düzce İl'inde yapılmış olan çalışmaya bağlı olarak da GETAT sektörünün, bölgesel ekonomik kalkınmada bir kaldıraç etkisinin olup olmadığ 1 analiz edilmiştir.

$\mathrm{Bu}$ anlamda ekonomi politikasının amacı kalkınma ve büyüme yoluyla refahı artırmaktır. Refahı artırmaktan amaç; başta dar gelirliler ve yoksullar olmak üzere, milli gelirden yeterince pay alamayanlarla birlikte toplumun tüm kesimlerinin yaşam kalitesinin yükseltilmesi neticesinde huzur ve mutluluğun artırılmasıdır. Refah artışı, gelir ve servet artışından elde edilen kaynakların adil bir şekilde dağıtılmasıyla meydana gelir. Bu açıdan ekonomi politikası, halkın refahı, mutluluğu, geleceğe olan güveni ve ekonomiye olan güveni gibi çeşitli boyutlarda değerlendirilmektedir. Ülkelerin ekonomik yapılarının kalkındırılması ile toplumsal refah seviyesinin de yükseltilmesi hedeflenen bir faaliyettir. Ekonomik kalkınmışlık düzeyinin yeterli düzeyde olması toplumun daha iyi şartlarda bir yaşam sürdürdüğünün bir göstergesi olabilmektedir. Bu doğrultuda ülkeler kendi ekonomik yapılarını kalkındırmak ve toplumun daha varlıklı ve daha yüksek bir refah ortamında yaşamasını hedef edinmektedir. Görüldüğü üzere ekonomik kalkınma, sayısal bir olgu veya bir hedeften ziyade ekonomideki niteliksel gelişimleri de ifade ettiğini gösterir. Bir ülkede iktisadi büyümenin yaşanması, daha çok hizmet ve mal üretiminin olmasına bağlıyken iktisadi kalkınma yalnız bununla yetinmez. Diğer taraftan üretilen malların kalitesinde, Pazar süreçlerindeki iyileşmelerinde veya toplumun yaşam standartlarında da iyileşmeleri kapsamaktadır (Yüksel ve Eraslan, 2015).

Ekonomik kalkınma, bölgesel gelişim ve bu programlara bağlı olarak sektörlerin ve sektörlerde faaliyet gösteren oyuncuların küresel rekabetçilik gücünü elde etmesi ve örgütlerin sürdürülebilir hale getirilmesi amacı ile önemli bir 
yaklaşım olarak görülen endüstriyel kümelenme yapılanmaları 1990'lı yıllardan itibaren gündemdeki yerini sürekli korumaktadır (Eraslan ve Dönmez, 2017, s. 326).

Küreselleşme, aynı zamanda, temel etkenler (ekonomik, sosyolojik, teknolojik vs.) ile birlikte firma-sektör-bölge-ülke rekabetçiliğini de üst düzeye çıkarmıştır. Diğer bir ifade ile artık sürdürülebilir rekabet avantajı elde edebilen uluslar ekonomik olarak hayatta kalabilmekte ve var olma yarışını sürdürebilmektedirler. Bu ekonomik mücadelede en önemli enstrümanlardan birisi kuşkusuz güçlü ve etkin stratejileri kurgulayabilme yeteneğidir. Günümüzde durmaksızın devam eden gelişmelerin ve yenilikçiliğin her alanda olduğu gibi sağlık sektöründe de yaşanması kaçınılmaz bir durum olmuştur. Binaenaleyh, bugün dünya ülkelerinin çoğu GETAT $^{3}$ uygulamalarına yönelmekte ve sektöre yönelik yeni yatırımlar gerçekleştirmektedir. Çünkü son yıllarda artan kullanım oranları sektöre yeni bir boyut kazandırmıştır.

Nitekim Dünya Sağlık Örgütü (DSÖ) 2019 raporuna göre GETAT uygulamalarının kullanım sıklığı birtakım ülkeler bazında Küba'da \%40 ila \%99 (uygulama türüne göre) arasında, Pakistan nüfusunun \%40 ila \%59'u, Birleşik Arap Emirlikleri ortalama \%45, Almanya ortalama \%50, Norveç ortalama \%30, Bangladeş ortalama \%30, Endonezya ortalama \%50, Malezya \%29, Brezilya yaklaşık \%20, Güney Afrika yaklaşı \%20 civarındadır (WHO, 2019). Yine DSÖ 2019 raporuna göre bölgeler bazında ise Güneydoğu Asya Bölgesi \%91, Afrika Bölgesi \%87, Amerika bölgesi \%80, Doğu Akdeniz Bölgesi \%90, Avrupa Bölgesi \%89 ve Batı Pasifik Bölgesi \%93 oranında kullanım sıklığının olduğu belirtilmiştir (WHO, 2019).

\footnotetext{
${ }^{3}$ Modern tıp kavramı, M.Ö. (460- 356) Hipokrat'ın tıbbın teşhis, tedavi ve prognoz süreçlerinin ayrıntılı bir gözlem, biriktirilmiş deneyim ve neden-sonuç ilişkisi üzerine inşa edilmesi gerektiği düşüncesi ile doğmuştur. Hipokrat'tan sonra modern tıp rahipler ve hekimler tarafindan uygulanan ampirik tedavi, sihir ve dini inanç gibi uygulamaların bir karışımı olarak değil de birikmiş deneyimlerle gerçek bilim haline gelmiştir (Grammaticos ve Diamantis, 2008, s. 2). Devamında (19. yy. başı) tıbbi uygulamaların bilimsel araştırma sonuçları ile gerçekleştirilmesine önem verilmiş ve kanıta dayalı tıp olarak literatürde yer edinmiştir. Biyokimya ve farmakoloji gibi tıbbın temel bilimlerinin de katkılarıyla hastalıkların teşhisi, tedavisi ve rehabilitasyonu sürecinde büyük gelişmelerle günümüze kadar gelişerek gelmesi sağlanmıştır (Şahin, 2017, s. 160). Ancak modern tıbbın çeşitli hastalıkların tedavisinde yetersiz kalması ve mali yükünün de ağır olması insanları yeni çareler aramaya sevk etmiştir. Gelecek yıllarda kullanımı daha çok artacak olan bu uygulamalara yönelik yeni sağlık stratejilerinin geliştirilmesi esas önemli konu olacağı beklenmektedir (Debas vd., 2006, s. 1281; Tekiner, 2019, ss. 54-55). Özellikle kronik ve malign gibi hastalıklar günümüzde artı̧̧ göstermiş ve insan hayatı üzerindeki etkileri de buna paralel olarak artmıştır. Bu durum kimyasal ilaç kullanımının zararlı etkilerinden kaçınmak ve sağlık çalışanlarının hastalara yeterli zaman ayıramaması ve ilgi gösterememeleri gibi çeşitli nedenlerden dolayı hastaların GETAT uygulamalarına olan ilgilerinin de artmasının yolunu açmıştır (Ünal ve Dağdeviren, 2019, s. 1).
} 


\section{DÜNYADA GELENEKSEL VE TAMAMLAYICI TIP (GETAT) SEKTÖRÜNÜN GENEL YAPISI}

GETAT, özellikle yaşam tarzı ile ilgili kronik hastalıkların önlenmesi ve yönetiminde ve yaşlanan nüfusun sağlık ihtiyaçlarını karşılamada birçok uygulama ile önemli ve hafif tedavi yöntemlerini içeren uygulamalardır. Birçok ülke, hasta bakım beklentilerinin arttığ 1 , maliyetlerin yükseldiği ve bütçelerin azaldığı ve yetersiz olduğu bir zamanda temel sağlık hizmetlerinin kapsamını genişletmeye çalışmaktadır. 21. Yüzyılın eşsiz sağlık zorlukları göz önüne alındığında, GETAT'a olan ilgi yeniden canlılık kazanmıştır. Bugün dünyanın birçok bölgesinde GETAT iyileştirici hizmetleri, önleyici bakım ile dengeleyen ve işleyişi oldukça basit olan insan merkezli bir sağlık sistemi seçeneği olmuştur (WHO, 2019, s. 5).

DSÖ, yayınlamış olduğu raporlarında küresel sağlık sistemleri içerisinde GETAT'1 da ayrı ve önemli bir sektör olarak kabul etmiştir. Aynı zamanda DSÖ birçok ülkede bu sektörel uygulamaların yasal veya yasal olmayan yollarla uygulandığını belirtmiştir. GETAT uygulamalarının mevcut sağlık sistemlerine eklemlendirilmesi ile daha etkin ve güvenli bir şekilde kullanımının teşvik edileceği belirtilmektedir (WHO, 2001; WHO, 2019). Nitekim 2014-2023 Geleneksel Tip Stratejisi raporunda bu amaç da güdülmüştür ${ }^{4}$.

DSÖ'ne göre, gelişmekte olan ülkelerdeki nüfusun \%60 ila 90'1 geleneksel tıp yöntemlerine başvurmaktadır. ABD, Avustralya, Fransa ve Almanya gibi gelişmiş ülkelerde ise nüfusun \%40'ından fazlası yılda en az bir kez GETAT uygulamalarını kullanmaktadırlar. Çin Halk Cumhuriyeti (ÇHC), Japonya, Güney Kore ve Tayvan gibi Asya ülkeleri geleneksel tıpta modern eğitim sistemleri geliştirmişlerdir (Park vd., 2016, s. 376). Aynı zamanda ABD pazarında sektöre yönelik milyarlarca dolarlık bir harcamanın yapıldığı ve bu açıdan ABD ekonomisi için önem arz ettiği belirtilmektedir. Özellikle kanser hastalarında sıkça kullanılan yöntemlerin yanı sıra diğer birçok GETAT uygulamasına da başvurulmaktadır (Johnson, 2018, s. 1376). Amerika'da 1997 yılında yapılmış bir çalışmanın sonuçlarına göre araştırmaya dâhil edilen yetişkin nüfusun \%42,1'inin GETAT uygulamalarından en az birini kullandığ 1 belirlenmiştir. 1997 yılında GETAT tedavilerinin kullanım oranları \%32 ile \%54 aralığında değişim göstermiştir (WHO, 2001, ss. 65-66). Genel anlamda ise ABD nüfusunun \%40'nın GETAT

${ }^{4}$ DSÖ’nün 2014-2023 Geleneksel Tıp Stratejisi raporunda sağlık öncülerinin daha geniş ve hasta özerkliği vizyonu ile çözümler geliştirebilmesi öngörülmektedir. Strateji raporunda iki temel amaç belirlenmiştir; (1) DSÖ’ne üye devletlerin sağlık, iyilik hali ve insan merkezli sağlık hizmetlerine katkı sağlamaları konusunda destek olmak, (2) ürün, uygulama ve uygulayıcıların düzenlenmeleri ile GETAT'ın güvenli ve etkili kullanımını teşvik etmektir. Bu amaçlara ulaşmak için de üç stratejik hedef belirlenmiştir. Bunlar; (1) bilgi tabanı ve ulusal politikaların oluşturulmasi; (2) güvenlik, kalite ve etkililiğin güçlendirilmesi ve (3) GETAT sistemini ve özbakım hizmetlerini ulusal sağlık sistemlerine entegre ederek evrensel sağlık kapsamının desteklenmesi şeklindedir (WHO, 2013, s. 8). 
uygulamalarına başvurduğu ve modern tıptan daha çok etkili olduğu belirtilmektedir (EFCAM, 2019).

ÇHC (\%40), Kolombiya (\%40), Şili (\%71) ve bazı Afrika ülkeleri $(\% 80)$ gibi birçok gelişmekte olan ülkede GETAT uygulamaları önemli oranlarda kullanılmaktadır (Fırat, 2019, s. 64; Ünal ve Dağdeviren, 2019, s. 6). Bazı sanayileşmiş ülkelerde, nüfusun neredeyse yarısı düzenli olarak bir çeşit GETAT uygulaması kullanıyorken, Kanada ve Almanya için rakamlar sırasıyla \%70 ve $\% 71$ ila \%75 düzeylerindedir. Avustralya'da ise farmasötik ilaçlardan çok GETAT ürünlerine harcama yapılmaktadır (Bodeker ve Burford, 2007, s. XV). Etiyopya nüfusunun yaklaşık \%80'i GETAT uygulamalarına başvurmaktadır. Bunun en büyük nedenlerinden biri modern tıp ulaşımında zorluklar yaşanmasıdır. Buna bağlı olarak 1948 yılında yasalaştırılan GETAT uygulamaları 1978 yılından sonra da Sağlık Bakanlığı'na bağlı olarak hizmet vermektedir (Karahancı vd., 2016, s. 1119).

Endonezya'da tüm nüfusun \%40'1 kırsal nüfusun ise \%70'i tarafindan GETAT uygulamaları kullanılmaktadır (Debas vd., 2006, s. 1282). Butan'da 103 temel geleneksel ilaç tedavisi ücretsiz bir şekilde vatandaşlara sunulmaktadır (McKay ve Wangchuk, 2018, s. 208). GETAT uygulamalarına başvuru diğer birçok ülkede de dikkat çekmektedir. Örneğin bu uygulamaların kullanımı ile ilgili araştırmalar; Suudi Arabistan (Al-Faris ve diğerleri, 2008), Almanya (Ernst, 2008), Misır (El-Dahshan vd., 2015), Japonya (Hori vd., 2008), İskoçya (Thomson vd., 2012) ve Türkiye (Erci, 2007), Hindistan (Singh, 2004; Pal, 2002) dahil olmak üzere çeşitli ülkelerde gerçekleştirilmiştir. Tamamlayıcı tedavileri kullanan kişi sayısı bu anket raporlarında değişiklik göstermiştir, ancak rapor edilen tüm ülkelerde kullanım yüzdesi \%50'ye yakındır (Lindquist vd., 2013, s. 6). DSÖ'nün GETAT'a yönelik iş birliği merkezlerinin sayılarına bakıldığında ise aşağıdaki (Tablo 1 bkz.) gibi bir izlenim ortaya çıkmaktadır. DSÖ ile GETAT alanında en fazla iş birliği merkezi sayısı ÇHC'ne (10) aittir. Bunu sırası ile Japonya (2), Kuzey Kore (2) ve Hindistan (2) takip etmektedir.

Tablo 1: DSÖ’ne Üye Ülkelerin GETAT Alanındaki İş Birliği Merkezleri Say1s1

\begin{tabular}{|l|c|}
\hline \multicolumn{1}{|c|}{ Ülke } & İş Birliği Yapan GETAT Merkezi Sayısı \\
\hline ÇHC & 10 \\
\hline Japonya & 2 \\
\hline Kore Cumhuriyeti & 2 \\
\hline Hindistan & 2 \\
\hline ABD & 1 \\
\hline Norveç & 1 \\
\hline İtalya & 1 \\
\hline Avusturalya & 1 \\
\hline Tayland & 1 \\
\hline Vietnam & 1 \\
\hline Peru & 1 \\
\hline
\end{tabular}

Kaynak: DSÖ (WHO), 2020. 
Yıllarca ihmal edilen GETAT sektörü çoğu ülkenin sağlık sistemlerine eklemlendirmesi ile doğru, güvenilir ve kanıta dayalı bir hizmet olarak sunulmasında DSÖ önemli çalışmalar yürütmüştür. Bugün birçok ülkede GETAT sektörüne yönelik düzenlemeler yapılmış ve yasal mevzuatlarla da desteklenmiştir. Çünkü GETAT uygulamalarının emin ellerde ve devlet güvencesi altında sunulması ile farklı bir boyut kazanabilmektedir. Buna bağlı olarak DSÖ çeşitli ülkelerle iş birliği içinde olup sektöre yönelik politikalar geliştirmektedir. $\mathrm{Bu}$ politikalar hem ülkelerin genel politik düzenlemesine hem de yereldeki düzenlemelerine katkılar sağlayabilmektedir (WHO, 2001; WHO 2013). DSÖ'nün GETAT sektörü üzerine yayınlamış olduğu raporlara göre bazı ülkelerin genel durumu Tablo 2'deki gibi analiz edilmiştir. Elde edilen son verilere göre GETAT'a yönelik ÇHC'nde 177 kuruluş, Türkiye'de 46 kuruluş, Belçika'da 35 dernek, Danimarka'da 2 dernek, Hindistan'da 7 enstitü, Japonya'da 3 enstitü, İtalya'da 1 enstitü ve Norveç'te 1 enstitü kurulduğu bildirilmektedir. Diğer taraftan GETAT uygulamas1 yapılan kamu ve özel hastane sayılarına bakıldığında Hindistan (2.860), ÇHC (2.500), Kuzey Kore (128) ve 206 kamu sağllğ merkezi şeklinde dağılım göstermektedir.

Tablo 2: Ülkelere Göre GETAT Sektörünün Durumu

\begin{tabular}{|l|c|c|c|c|c|c|}
\hline \multicolumn{1}{|c|}{ Ülkeler } & $\begin{array}{c}\text { GETAT } \\
\text { Ulusal } \\
\text { Politika }\end{array}$ & $\begin{array}{c}\text { GETAT } \\
\text { Yönetmelik }\end{array}$ & $\begin{array}{c}\text { GETAT } \\
\text { Ulusal } \\
\text { Araştırma } \\
\text { Kurumu }\end{array}$ & $\begin{array}{c}\text { GETAT } \\
\text { Uygulama } \\
\text { Hastanesi }\end{array}$ & $\begin{array}{c}\text { Yasal Sinırlı } \\
\text { Uygulamalar }\end{array}$ & $\begin{array}{c}\text { Toplam Tüketimdeki } \\
\text { Geleneksel İlaçların } \\
\text { Payı }\end{array}$ \\
\hline ÇHC & + & + & + & + & + & $\% 30-\% 50$ \\
\hline $\begin{array}{l}\text { Kuzey } \\
\text { Kore }\end{array}$ & + & + & + & + & + & $3 \%$ \\
\hline Hindistan & + & + & + & + & + & Veri yok \\
\hline Japonya & + & + & + & + & + & $83 \%$ \\
\hline Avustralya & + & + & + & + & + & Veri yok \\
\hline Almanya & + & + & + & + & + & $\% 20-\% 30$ \\
\hline Norvec & + & + & + & + & + & Veri yok \\
\hline Kanada & + & + & + & + & + & $24 \%$ \\
\hline ABD & + & + & + & + & + & Veri yok \\
\hline Türkiye & + & + & + & + & + & Veri yok \\
\hline Küba & + & + & + & Veri yok & + & Veri yok \\
\hline İtalya & + & + & + & + & + & Veri yok \\
\hline
\end{tabular}

Kaynak: Biçer ve Yalçın Balçık, 2019, s. 251.

Küresel boyutta GETAT uygulamalarının hızlı bir şekilde yayılım gösterdiği ve özellikle son y1llarda devletlerin bu konu üzerine eğilim gösterdiği dikkat çekicidir. Giderek önem kazanan sektör, modern tıbbın yanında yasal uygulayıcılar tarafindan sunulmaktadır. Dahası sektörün kanıta dayalı, bilimsel çalışmalar ve uygulamalar 1şı̆̆ında hizmet vermesini sağlamak için yoğun dönüşümler gerçekleşmekte ve yükseköğretim kurumlarında program statüsü kazanmaktadır. Nitekim Tablo 2'de de görüldüğü üzere sektörün yasalaştırılmasının dışında enstitülerin kurulduğu ve sektöre bir yükseköğretim boyutunun kazandırıldığı anlaşılmaktadır. Sektörün gelecekte başlı başına tıbbın 
özerk bir alanı olmaya yönelik potansiyele sahip olduğu görülebilmektedir. $\mathrm{Bu}$ anlamda GETAT'a yönelik düzenlemelerin hız kazanması ve sektörün geliştirilmesine daha çok önem verilmesi üstün rekabet sağlayabilmede bir firsat yaratabilecektir.

\section{TÜRKIYE'DE GELENEKSEL VE TAMAMLAYICI TIP (GETAT) SEKTÖRÜNÜN GENEL YAPISI}

Dünyanın birçok yerinde olduğu gibi Türkiye'de de GETAT uygulamalarına yoğun bir şekilde başvurulduğu bilinmektedir. Başvurulan bu uygulamaların bir kısmı yasalarla güvence altına alınmışken çoğu yöntem yasal olmayıp merdiven altı uygulamalarla gerçekleştirilmektedir (Turan vd., 2010, 104; Somer ve Vatanoğlu, 2017, s. 62). Türkiye'de GETAT sektörüne ilişkin ilk düzenleme 1991 yılında resmî gazetede yayınlanan Akupunktur Tedavi Yönetmeliği ile gerçekleşmiştir. Tedavi yöntemine yönelik çıkarılan yönetmelikte temel amaç akupunktur uygulamasının da esas ve usulleri belirlenip diğer tedavi yöntemleri gibi bilimsel tekniklerle yapılmasını sağlamaktı (T.C. Resmî Gazete- 1, 1991, s. 3).

Yönetmelikte akupunktur tedavi yönteminin nasıl uygulanacağı ve bu uygulamaların kimlerin yapabileceğine yönelik genel bir çerçeve belirlenmiştir. Uygulamanın ve verilecek eğitimin denetlenmesi için de bir üst kurul oluşturulmuştur (Mollahaliloğlu vd., 2015, s. 103; Biçer ve Yalçın Balçık, 2019, s. 248). Sektörün bir konu olarak ders niteliği taşıması 2001 yılına denk gelmiş ve İstanbul Üniversitesi Onkoloji Enstitüsünde Tamamlayıc1 Tıp bölümü kurularak dersler verilmeye başlanmıştır (Çelik Yılmaz, 2017, s. 11).

2002 yılına gelindiğinde alana ilişkin yeni bir yönetmelik yayınlanmış ve buna göre akupunktur uygulaması yapacak olan özel sağlık kurumlarına ilişkin usul ve esaslar belirlenmiştir. 1991 yllında oluşturulan üst kurul da değiştirilerek bilimsel kurula dönüştürülmüştür (T.C. Resmî Gazete- 2, 2002; Mollahaliloğlu vd., 2015, s. 103).

$\mathrm{Bu}$ doğrultuda akupunktur uygulamasına dair ders müfredatı ve eğitim süresi belirlenmiştir. Bazı üniversiteler Sağlık Bakanlığı tarafından eğitim almış ve akupunktur konusunda eğitim vermeye ve uygulama yapmaya başlamıştır. Daha sonra konuya ilişkin yurt dışı ve yurt içi sertifika eğitimi almış olan hekimler, resmi komisyon tarafından sınava tabii tutulmuş ve başarı gösteren hekimler uygulama yetkisi almıştır. Sonuç olarak akupunktur uygulaması Türkiye'de de kabul görmüş ve uygulanmaya başlanmıştır (Mollahaliloğlu vd., 2015, s. 103).

Sağlık alanının en önde gelen ve en kapsamlı araştırmalarını yapan bir organizasyon olarak DSÖ, daha önce alternatif, geleneksel, tamamlayıc1, folk, halk tıbb1 vb., kavramlarla anılan sektörün Geleneksel ve Tamamlayıcı Tip (GETAT) olarak ele alınması gerektiğini öne sürmüş ve alandaki birçok tartı̧̧maya da son vermiştir (Kökten, 2017, s. 1). Türkiye'de de 2014 yılında 29158 sayı ile resmî gazetede yayınlanan Kanun Hükmünde Kararname'ye göre Geleneksel ve 
Tamamlayıcı Tip Uygulamaları Yönetmeliği şeklinde değerlendirilmiştir. Yönetmelikte GETAT uygulamalarına yönelik toplamda 15 başlık belirlenmiş ve sektöre yeni bir boyut kazandırılmıştır (T.C. Resmî Gazete-3, 2014, s. 3).

Yönetmelik çerçevesinde amaç, kapsam ve yasal dayanak açık ve net bir şekilde ortaya koyulmuştur. Bu bağlamda yönetmelikle yöntemleri uygulayacak kişiler ve sağlık kuruluşlarının yanı sıra hangi hastalıklar için hangi yöntemlerin uygulanabileceği de belirtilmiştir. Akupunktur gibi diğer 14 tane uygulama da bu yönetmelik dahilinde tanımlanmıştır (Mollahaliloğlu vd., 2015, s. 103). Aşağıdaki tabloda belirlenen GETAT uygulamaları analiz edilmiştir.

Aşağıda yer alan tabloda değerlendirilen 15 GETAT uygulaması yasal güvence altına alınmış ve sağlık kuruluşlarında hekimlerin kontrolünde uygulanmaktadır. Geleneksel ve Tamamlayıcı Tıp Uygulamaları Daire Başkanlığ sitesine göre Türkiye'de üniversitelere bağlı 12 GETAT eğitim merkezi, Sağlık Bakanlığı ve Üniversitelere bağlı toplamda 65 tane de uygulama merkezi bulunmaktadır. Uygulama merkezlerinden 26 tanesi üniversitelere bağlıyken diğer 39 tanesi de direk Sağlık Bakanlığına bağlıdır (Getatportal, 2020).

Tablo 3: Yönetmelik Dâhilinde Uygulanan GETAT Yöntemleri

\begin{tabular}{|c|c|c|}
\hline $\begin{array}{l}\text { GETAT } \\
\text { Yöntemi }\end{array}$ & Tanım & Referans \\
\hline Akupunktur & $\begin{array}{l}\text { Vücudun belli noktalarında deri altına iğneler batırma şeklinde } \\
\text { bir uygulama }\end{array}$ & Sar1, 2016, s. 7 \\
\hline Apiterapi & $\begin{array}{l}\text { Bal arısı ve ürünleri aracılığıyla tedavi ve bütünsel şifa sanatı } \\
\text { ve bilimi }\end{array}$ & Ahuja ve Ahuja, 2011, s. 1 \\
\hline Fitoterapi & $\begin{array}{l}\text { Çeşitli bitkilerin kullanılmasıyla hastalara uygulanan bir tedavi } \\
\text { yöntemi }\end{array}$ & $\begin{array}{l}\text { Rao vd., 2012; Şarışen ve } \\
\text { Çalışkan, 2005, s. } 183\end{array}$ \\
\hline Hipnoz & $\begin{array}{l}\text { Hipnotist tarafından verilen komutlarla hastanın bilinçaltına } \\
\text { inerek hastada hafıza, algılama ve istemli hareket değişiminin } \\
\text { sağlanması }\end{array}$ & $\begin{array}{l}\text { Erel ve Erel, 2014, s. 46; } \\
\text { Özgök, 2013, s. } 11\end{array}$ \\
\hline $\begin{array}{l}\text { Sülük } \\
\text { Uygulamas1 }\end{array}$ & $\begin{array}{l}\text { Hastanın vücuduna yerleştirilen tıbbi sülüklerle sağlık } \\
\text { durumunun düzeltilmesi }\end{array}$ & $\begin{array}{l}\text { Ayhan ve Mollahaliloğlu, } \\
2018, \text { s. } 141\end{array}$ \\
\hline Homeopati & $\begin{array}{l}\text { Her insanın kendine özgü bir vücut yapısı ve sağlık durumu } \\
\text { olduğunu kabul eden, hastanın sözel hikâyesine başvurularak } \\
\text { uygulanan, bütünüyle doğal yöntemler kullanan, fiziksel, } \\
\text { zihinsel, ruhsal ve duygusal iyileşmede etkili, bütüncül bir } \\
\text { tedavi yöntemi }\end{array}$ & $\begin{array}{l}\text { Arslan, Şahne ve Şar, 2013, } \\
\text { s. } 48\end{array}$ \\
\hline Kayropraktik & $\begin{array}{l}\text { Manuel bir teknik olan yöntem bozulmuş kas ve iskelet } \\
\text { sisteminin teşhis edilmesi, tedavisi ve bu bozuklukların } \\
\text { önlenmesi }\end{array}$ & WHO, 2005, s. 10 \\
\hline Kupa (Hacamat) & $\begin{array}{l}\text { Herhangi bir hastalıktan dolayı veya sağlıklı kalmak } \\
\text { maksadıyla vücudun belli bölgelerini hafifçe çizip üzerine } \\
\text { boynuz, bardak veya şişe oturtarak kan alma işlemi }\end{array}$ & Işı1k ve Aksoy, 2012 \\
\hline $\begin{array}{l}\text { Larva } \\
\text { Uygulamas1 }\end{array}$ & $\begin{array}{l}\text { Lucilia soyundan olan Lucilia (Phaenicia) sericata sineğinin } \\
\text { steril bir hale getirilen larvalarının kronik yaraların tedavisinde } \\
\text { kullanılması }\end{array}$ & Tanyüksel vd., 2014, s. 218 \\
\hline Mezoterapo & $\begin{array}{l}\text { Mineral ve vitaminlerin, çeşitli ilaç ve aminoasitlerin ağrısız } \\
\text { enjeksiyonlarla, kökeni mezoderme dayanan deri içi ve deri } \\
\text { altına enjekte edilmesidir }\end{array}$ & Özmen vd., 2005, s. 196 \\
\hline Proloterapi & $\begin{array}{l}\text { Enjeksiyon bazlı bir yöntem olan proloterapi kes ve iskelet } \\
\text { ağrılarına uygulanır }\end{array}$ & Rabago, 2010, s. 65 \\
\hline Osteopati & $\begin{array}{l}\text { Uygulayıcıların manuel bir uygulama ile hastanın kas ve } \\
\text { iskelet bozukluklarına yönelik uyguladığı bütüncül bir tedavi }\end{array}$ & $\begin{array}{l}\text { Kaya ve Altınbilek, 2019, s. } \\
86\end{array}$ \\
\hline
\end{tabular}




\begin{tabular}{|l|l|l|}
\hline & yöntemi & \\
\hline $\begin{array}{l}\text { Ozon } \\
\text { Uygulamas1 }\end{array}$ & $\begin{array}{l}\text { Ozon ve oksijen karışımının belli bir miktarda karıştırılması ve } \\
\text { bunun vücut boşluklarına veya dolaşım sistemine uygulanması }\end{array}$ & Özler vd., 2009, s. 59 \\
\hline Refleksoloji & $\begin{array}{l}\text { Tüm organlar, salgı bezleri ve vücut bölümleri ile ilişkili olan } \\
\text { ayaklarda, kulaklarda ve ellerdeki refleks noktalarına manuel } \\
\text { uygulama ile vücut fonksiyonlarının normalleştiren bir teknik }\end{array}$ & Korkan ve Uyar, 2014, s. 9 \\
\hline Müzikterapi & $\begin{array}{l}\text { Davranış, duygu veya fizyolojik değişiklikleri etkileme } \\
\text { yöntemi veya bir hastalı̆̆ı veya sakatlı̆̆ı tedavisi için } \\
\text { bireyin fizyolojik, psikolojik ve duygusal entegrasyonunu } \\
\text { sağlama yöntemidir. Müzikterapisi ruhsal bozukluğa } \\
\text { yöneliktir. }\end{array}$ & $\begin{array}{l}\text { Covington ve Crosby, 1997, } \\
\text { Syar ve Akın Korhan, 2011, } \\
\text { s. 140 }\end{array}$ \\
\hline
\end{tabular}

Son yıllarda küresel anlamda önem kazanan sektör daha çok bilimsel çalışmalarla desteklenmeye çalış1makta ve mevcut sağlık sistemlerine uyumu sağlanmaktadır. Türkiye bu açıdan son 5 yıllık bir süreçte sektöre yönelik birtakım gelişmeler göstermiş ve tamamen devlet eli ile yapılmaya çalışılmıştır. Ar-Ge merkezleri, deney laboratuvarları, gözlem odaları, eğitim merkezleri gibi çeşitli çalışmaların yapılmasından sonra GETAT klinik araştırma ilkeleri ve eğitimlerine de ağırlık verilmeye başlanmıştır. Bu anlamda uzman ve profesyoneller tarafından yapılan çalışmalarla Sağlık Bakanlığı'nın da izinleri çerçevesinde sektör kapsamında geliştirilen GETAT yöntemleri veya ilaçları ile tedaviler sağlanmaktadır. Nitekim çeşitli sağlık kuruluşlarında poliklinik düzeyinde hizmet vermeye başlamıştır. Sektör uygulamalarına yönelik Iyi Klinik Uygulamaları Kılavuzu yayınlanmış ve klinik verilerin uluslararası karşılıklı kabulünü kolaylaştırmak için tek bir standart sağlama amacı benimsenmiştir (Getatportal, 2020).

Türkiye yasalardan aldığı görev ve yetkilerle, Sağlık Bakanlığı GETAT'ın kanıta dayalı bilimsel çalışmalarla desteklenip sağlık sistemine entegre amacı ile stratejik plan hazırlamış ve yürürlüğe koymuştur. $\mathrm{Bu}$ amaçla yukarıda da belirtildiği gibi mevzuat çalışmaları yapılmış ve nihayetinde Geleneksel ve Tamamlayıcı Tıp Uygulamaları Yönetmeliği yayımlanmış ve hukuk alt yapısı bina edilmiştir. 20'ye yakın Üniversitemizde Geleneksel ve Tamamlayıcı Tıp Uygulama Merkezi hizmet vermekte olup (Ar-Ge ve Eğitim Merkezleri), 500'e yakın Geleneksel ve Tamamlayıcı Tıp Uygulamaları Ünitesi açılmış, 14 Sertifikalı Uygulama alanında yaklaşık olarak 5.000 sertifika verilmiştir. Diğer taraftan Sağlık Bakanlığ bünyesinde, uluslararası işbirlikleri geliştirmek için kamu kurum ve kuruluşları ile sivil toplum kuruluşları nezdinde çalışmalar yapılmaktadır. Cumhurbaşkanlığı'nın doğrudan destekleri ile geliştirilmeye çalışılan sektöre yönelik 24- 27 Nisan 2019 tarihli birçok Ulusal ve Uluslararası ülkenin de katılımları ile Kronik Hastalıklarda Geleneksel ve Tamamlayıcı Tip Uygulamaları temalı kongre düzenlenmiştir. Bu bağlamda katılım sağlayacak yaklaşık 30 ülkeden temsilcilerle görüşmeler yürütülmüştür (S.B., 2019, s. 5).

\section{REKABETÇİLIK ANALIZIINDE ELMAS MODELİ YAKLAŞIMI}

Uzaklık sınırlarının ortadan kalkması ile birlikte küreselleşen dünyada uluslar kendilerini daha sert bir rekabetin pençesinde bulmuşlardır. Bu rekabet 
ortamında da sektörler daha çok önem kazanmaya başlamıştır (Porter, 1990, s. 2). Ancak strateji kavramının da buna paralel bir çizgide gelişim göstermesi rekabet üstünlüğü elde etmek için yeni firsatlar yaratmıştır (Porter, 1989, s. 1). Konu irdelendiği zaman rekabet gücü devamlılığının, dinamik bir yapı olan yenilikçilik, verimlilik ve girişimcilik gibi unsurlara göre şekillendiği anlaşılacaktır. $\mathrm{Bu}$ sayede yenilikçilik ve verimliliğin teşvik edilmesi ile rekabet gücü artırılabilmektedir (Magretta, 2012; Porter ve Van Der Linde, 1995, ss. 1-2).

1990 y1linda Porter tarafindan yayınlanan Ulusların Rekabet Avantaj1 (The Competitive Advantage of Nations) kitabinda neden bazl uluslar diğer uluslara göre daha rekabetçidir? Sorusuna cevap aranmıştır. Sorunun temelinde yatan nedenleri anlayabilmek için de kendi geliştirmiş olduğu Elmas Modeli yaklaşımı ile ulus endüstrilerinin rekabet gücünü analiz etmiştir. Model, küresel rekabet unsurlarını bir sistem yaklaşımı içinde analiz ederek ulusal rekabet avantajlarının belirleyicilerini ortaya koymayı amaçlamaktadır (Bulu vd., 2006, s. 5; Eraslan vd., 2007, s. 5; Bulu vd., 2007, s. 5; Eraslan vd., 2008b, s. 16). Nitekim Porter'ın Elmas Modeli, on ülkede bulunan birçok sayıdaki sektörün araştırmalarına dayanan dört yıllık bir çalışmanın sonucunda şekillenmiştir (Neven ve Droge, 2001, s. 3). Ayrıca Elmas Modeli kullanılarak küresel çerçevede 10 önemli ticaret ülkesi olan Danimarka, Almanya, İtalya, Japonya, Kore, Singapur, İsveç, İsviçre ve Birleşik Krallık gibi ülkeler hakkında incelemeler yapmıştır (Porter, 1990, s. 2).

Klasik iktisat kuramları, ülkelerin gelecek nesillere bırakabileceği ülke toprağı, doğal kaynaklar ve nüfus gibi faktör havuzlarının nispi avantajların belirleyicisi olduğunu ifade etmektedir. Sadece makro ekonomik değişkenleri, ucuz veya yoğun işgücünü, devlet politikalarını veya yönetim tekniklerini rekabet avantajlarının belirleyicisi olarak görmek de doğru sonuçlara ulaşmak için yeterli değildir. Porter, daha geçerli bir paradigmaya ulaşabilmek için özelleştirilmiş (niche) endüstrilere yoğunlaşmış ve rekabetçiliğin yukarıda sayılan unsurlardan etkilendiğini ancak bazı durumlarda bu unsurların yoğun-bol olmasının sürdürülebilir büyümenin önünde engel olabileceğini ifade etmiştir. Porter, ulusların nitelikli işgücü, güçlü teknoloji, bilgi birikimi ve kültür gibi kendi ileri faktör havuzlarını oluşturabileceğini ileri sürmüş ve bunun özelleşmiş koşullar altında gerçekleştiğini ifade etmiştir (Porter, 1990; Neven ve Dröge, 2001, ss. 4-5; Bulu vd., 2004, s. 4). Model sürdürülebilir rekabet üstünlüğü sağlamada kullanılabilecek bir araçtır. Çünkü sürdürülebilir bir rekabet avantajı olmadan, ortalamanın üstünde performans elde etmek güçtür (Eraslan, 2008a, s. 3).

Elmas yapıs1 gibi tasarlanan modelde herhangi bir sektörün rekabet avantajına etki eden dört ana eksen belirlenmişsir. Bu temel değişkenler elmasın köşelerini oluşturan girdi koşulları, firma stratejisi ve rekabet yapısı, talep koşulları, sektörel kümelenmedir. Devlet ise bu dört faktörü dışardan etkileyen bir başka değişken olarak modelde yer almaktadır. Rekabet avantajını belirleyen elmas modeli, bir sistem ortaya çıkarmakta, bu nedenle temel değişkenler tek tek değil, birlikte rekabet avantajlarını belirlemektedirler. Diğer bir deyişle, modelin dört 
köşesinde yer alan faktörler birbirlerini etkilemektedirler. Dolayısıyla sistem dinamik bir yapı kazanmaktadır (Bulu vd., 2006, s. 54).

Şekil 1'de görüldüğü üzere devlet değişkeninin modelin ana değişkenleri üzerinde dışsal bir etken olarak yer almaktadır. Modelin ana değişkenleri arasında on iki yönde içsel etkileşim bağlantısı bulunurken devletin de bu dört ana değişken üzerinde tek yönlü dört tane dışsal etki bağlantısı bulunmaktadır. Bu etkileşim bağlantılarının birbirlerine ve modelin bütününe etki derecesi bölgeden bölgeye, firmadan firmaya değişiklik göstermektedir. Elmas modeli bir faktörün diğer üç faktör tarafından nasıl etkilendiğini açıklayarak, sektörlerin rekabetçilik pozisyonlarını belirlemekte kullanılmaktadır.

Porter, bir endüstrinin rekabet gücü elde edebilmesi için gerekli olan üretim faktörlerini, girdi koşulları olarak değerlendirmiş̧ir (Jin ve Moon, 2006, s. 3). Girdi koşulları arasında nitelikli işgücü, sermaye kaynakları, ham maddeler, fiziki kaynaklar, bilgi kaynakları, teknolojik kaynaklar, altyapı, yöneticinin yetenekleri ve yenilikçilik gücü yer almaktadır (Bulu vd., 2006, s. 55; Aghdaie vd., 2012, s. 4). Nispi avantaj oluşumunda birincil rol oynayan bu faktörler uygulanan politikalar, teknolojik gelişmeler veya kültürel gelişmelere paralel olarak geliştirilebilir ve değiştirilebilir. Diğer yandan Porter, niteliksiz işgücü, hammadde gibi genel kullanıma açık faktörlerin ise herhangi bir firma tarafından elde edilebileceğini ve bu özellikleri nedeni ile rekabet avantajı sağlayamayacaklarını belirtmektedir (Bulu vd., 2006, s. 55).

Şekil 1: Rekabetçilikte Porter'1n Elmas Modeli

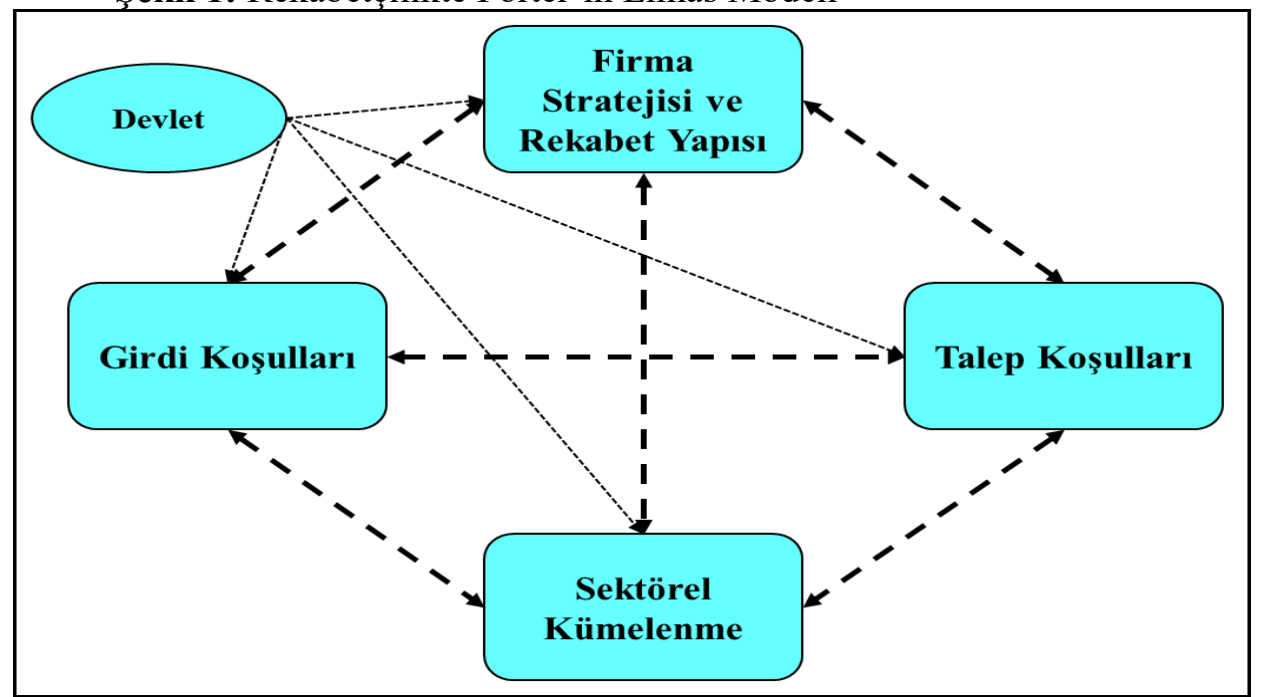

Kaynak: Porter, M.E. (1990). The Competitive Advantage of Nations. The MacMillan Press Ltd., London and Basingstoke, 1(1), 70-91.

Talep koşulları, bir sanayinin ürünlere yönelik talep koşullarını belirler ve ürün veya hizmet talebindeki artış, rekabet gücünü etkilemektedir. Diğer taraftan 
firmaların ürünlere yönelik önemini ve yenilikçilik düzeyine etki etmektedir. Mevcutla yetinmeyen ve çeşitlenmiş bir talep yapısı işletmeleri yeni ürünler geliştirmeye ve değişim yapmaya zorlarken, özellikle nicelik ve nitelik bağlamında iç talebin yüksek olması küresel pazarlarda işletmelere rekabet avantaj1 sağlamaktadır. Porter'a göre ulusların veya ulusal firmaların, geleceğin talep yapısı hakkında, iç talebin doğru sinyaller vermesi ve bu sinyallerin yabancı firmalardan önce yerel firmalar tarafindan algılanması ile rekabet avantajı elde edilebileceği belirtilmektedir (aktaran: Eraslan vd. 2007, s. 209). Ulusların endüstriyel rekabet gücüne etki eden bir diğer değişken de sektörel kümelenmedir. Kümelenme içinde yer alan firmaların rekabetçilik düzeyi ve yeterlilikleri rekabet avantajı düzeyini doğrudan etkilemektedir (Riasii, 2015, s. 5).

Kümelenme ilişkisi içindeki firmaların birbirlerinin başarısını etkilediği bilinmektedir. $\mathrm{Bu}$ yüzden firmalar arasındaki iç rekabet, ulusun küresel anlamdaki rekabet gücü üzerinde rol oynamaktadır. Sektörel kümelenmenin getirdiği en büyük avantajlardan bir tanesi de tedarik zincirinin sektöre yenilikçi ve ucuz girdi temini sağlamasıdır. Burada sektörler arasındaki yatay ve dikey ilişki ile bilgi alışverişi sağlanır ve devamında yenilikçiliği de tetikler (Eraslan vd., 2007, s. 209).

Firma stratejisi ve rekabet yapısı, firmaların nasıl kurulduğu, organize edildiği ve yönetildiği ve aynı zamanda ulusal rekabetin doğasını oluşturan koşullardır (Porter, 1990, s. 8). Porter, firma stratejisi ve rekabet yapısında firmaların kuruluş biçimleri, organizasyon yapıları, yönetim şekilleri ve ulusal rekabetçiliğini konu edinmiş̦tir. Firmanın stratejisi doğrudan firmanın yönetim şekillerinden etkilenmektedir. Kültürlerin yönetim şekilleri ise rekabet yapısı açısından firma ilişkileri ve organizasyon yapısı gibi unsurlar üzerinde olumlu ve olumsuz yönde etki yaratmaktadır. Tüm bu durumlar ulusal rekabet yapısını etkilerken ulusal rekabet yapısı da küresel rekabetçilikle doğrudan ilişkili olmaktadır. Firmaların iç piyasalardaki düşük rekabet gücü bir avantaj olsa da bölgesel bir rekabetin nitelikli olması, firmaları yenilikçilik yapmaya ve ekonomik olanakların ötesine geçmeye zorlayarak küresel rekabete hazırlar (Eraslan vd., 2007, s. 209).

Özetle Porter'ın Elmas Modeli, ulusal rekabet edebilirlik avantajlarının belirleyicilerini sistematik bir şekilde tanımlamak için küresel rekabet edebilirlik değişkenlerini sistematik bir yaklaşım içinde analiz etmektedir (Selli vd., 2010, s. 102). Model bir döngü olarak devamlı hareket halinde olup olumlu ve olumsuz etkilerin ortaya çıktı̆̆ 1 bir sistem oluşturmaktadır. Modelin her bir köşesini oluşturan değişkenler arasında devamlı bir etkileşim söz konusu olmaktadır (Timurçin, 2010, s. 63). Sistemin başarılı bir sonuç elde etmesi yani rekabet avantajının sağlanabilmesi yenilik ve yenilenmenin gidişatına bağlıdır. Bir değişkenden kaynaklanan etkinin faydalı bir hal alabilmesi diğer değişkenlerin durumuna bağlıdır. Her bir değişkene yansıyan etki iyi değerlendirilip diğer değişkenlere yansıdığında olumlu etkilenmeler ortaya çıkar. Geniş ve yaygın etkileşimin ortaya çıkması, sistem bütünü içindeki karşılıklı etkileşimin nitelik ve 
yoğunluğuna bağlı olup, tek bir etken, genelde yetersiz kalırken; yeni bilgi, yetenek ve oyuncuların sürekli devreye girdiği dinamik ve rekabetçi bir ortamın varlığ 1 küresel rekabet avantajını ortaya çıkarmaktadır (Eraslan vd., 2007, s. 209).

\section{ARAŞTIRMANIN YÖNTEMI}

Düzce İli Geleneksel ve Tamamlayıcı Tıp (GETAT) sektörünün uluslararası rekabetçilik pozisyonunu ortaya çıkarmak bu çalışmanın temel amacını oluşturmaktadır. $\mathrm{Bu}$ bağlamda, Düzce İli GETAT sektörünün uluslararası rekabetçilik düzeyi Porter'ın Elmas Modeli kullanılarak analiz edilmiş ve modelin değişkenleri çerçevesinde yorumlanmıştır.

Çalışmanın bilimsel araştırma yönteminde nitel ve nicel yaklaşımlar beraber kullanılmıştır. Nitekim bilimsel bir araştırma için nitel, nicel veya karma şeklinde üç yaklaşımdan söz edilebilir (Creswell, 2014, ss. 8-13). Bu çalışmanın veri toplama yönteminde karma (nitel -derinlemesine mülakat ve uzman görüşüve nicel -yarı yapılandırılmış anket tekniği- yaklaşımlar) yönteme başvurulmuştur. Araştırma verilerinin etik kurallar çerçevesinde ve güvenilir bir şekilde toplanabilmesi için, araştırma öncesinde Düzce Üniversitesi Girişimsel Olmayan Sağllk Araşstırmaları Etik Kurulu'na başvurulmuş ve 21.01.2019 tarih ve 2018253 sayılı araştırma izni alınmıştır.

\section{Araştırmanın Örneklemi}

Düzce Üniversitesi ve Düzce Üniversitesi hastanesinde GETAT sektörü ile ilgili öğrenci ve personel şeklinde toplamda 180 kişi tespit edilmiştir. Tespit edilen kişilerin tamamına 180 anket dağıtılmış ve tamamından geri dönüş sağlanmıştır. Ancak anket formlarından 7 tanesi özensiz ve analize uygun bir şekilde doldurulmadığından analiz dişı bırakılmıştır. Araştırmaya katılan bayan katılımc1ların sayıs1 $111(\% 64,2)$, erkek katılımciların sayıs1 $62(\% 35,8)$ 'dir. Katılımcılardan 58 kişi $(\% 33,5)$ 18-25 yaş aralığında, 69 kişi $(\% 39,9)$ 26-35 yaş aralı̆̆ında, 38 kişi $(\% 22,0)$ 36-45 yaş aralığında, 6 kişi $(\% 3,5)$ 46-55 yaş aralı̆̆ında ve 2 kişi $(\% 1,2) 56$ yaş ve üzeridir. 2 kişi $(\% 1,2)$ lise mezunu, 97 kişi $(\% 56,1)$ üniversite mezunu, 35 kişi $(\% 20,2)$ yüksek lisans mezunu ve 39 kişi $(\% 22,5)$ ise doktora mezunudur. Katılımcılardan 76 kişi $(\% 43,39)$ doktor çalışan, 51 kişi $(\% 29,5$ yardımcı sağlık personeli ve $46(\% 26,6)$ tanesi de GETAT öğrenci topluluğu üyesidir. Katılımcıların GETAT eğitim durumları incelendiğinde ise 27 $(\% 15,0)$ kişinin eğitim aldığ 1 ve $147(\% 85,0)$ kişinin de eğitim almadığ 1 bilgisine ulaşılmıştır.

Derinlemesine Mülakat tekniği de Düzce İli düzeyinde GETAT sektörüne hâkim ve alanda uzmanlık sahibi olan 20 katılımcı ile gerçekleştirilmiştir. Katılımcılardan elde edilen verilerin değerlendirilmesi sonucunda 5 mülakat verisi analiz dışı bırakılmış ve 15 katılımcıdan sağlanan veriler analiz edilmiştir. Derinlemesine mülakat tekniğine katılanların dağılımı Kimyager (3), Farmakolog (2), Kimya Mühendisi (2), Aile Hekimi (1), Biyolog (1), Biyoteknolog (1), Tibbi 
Fizyolog (1), Elektrik Mühendisi (1), Göğüs Hastalıkları Uzmanı (1), Kalite Uzmanı (1), İşletmeci (1) ve Aile Hekimi Asistanı (5) şeklindedir.

Araştırmanın üçüncü veri toplama tekniği olan uzman görüşü tekniğinde ise 3 uzman katılımc1 ile görüşmeler sağlanmış ve sektörle ilgili dünyadaki konumundan bilgiler alınmıştır. Katılımcılar sırası ile GETAT üretimi uzmanı, endüstri mühendisi ve tarım ekonomisi uzmanı şeklinde dağılım göstermiştir.

\section{Veri toplama Yöntemi}

Araştırmanın amacına ulaşmak için kullanılan ikincil veri toplama yönteminde sektörle ilgili yazılı ve görsel kaynaklar (ilgili sivil toplum kuruluşlarının, kamu kurum ve kuruluşlarının ve gazetelerin sektörel raporları, dernek kayıtları, ilgili internet kaynakları, bilimsel makaleler, firma kataloglar $v b$.) incelenmiştir.

Birincil veri toplama tekniği olarak derinlemesine mülakat, anket ve uzman görüşü yöntemine başvurulmuştur. Her bir veri toplama tekniği aşağıda Şekil 2'de verildiği gibi üst (5) ve alt (29) boyutlar çerçevesinde uygulanmış ve toplanan veriler de bu çerçevede değerlendirilmiştir.

Şekil 2: Veri Toplama Tekniklerine İlişkin Üst ve Alt Boyut değişkenleri

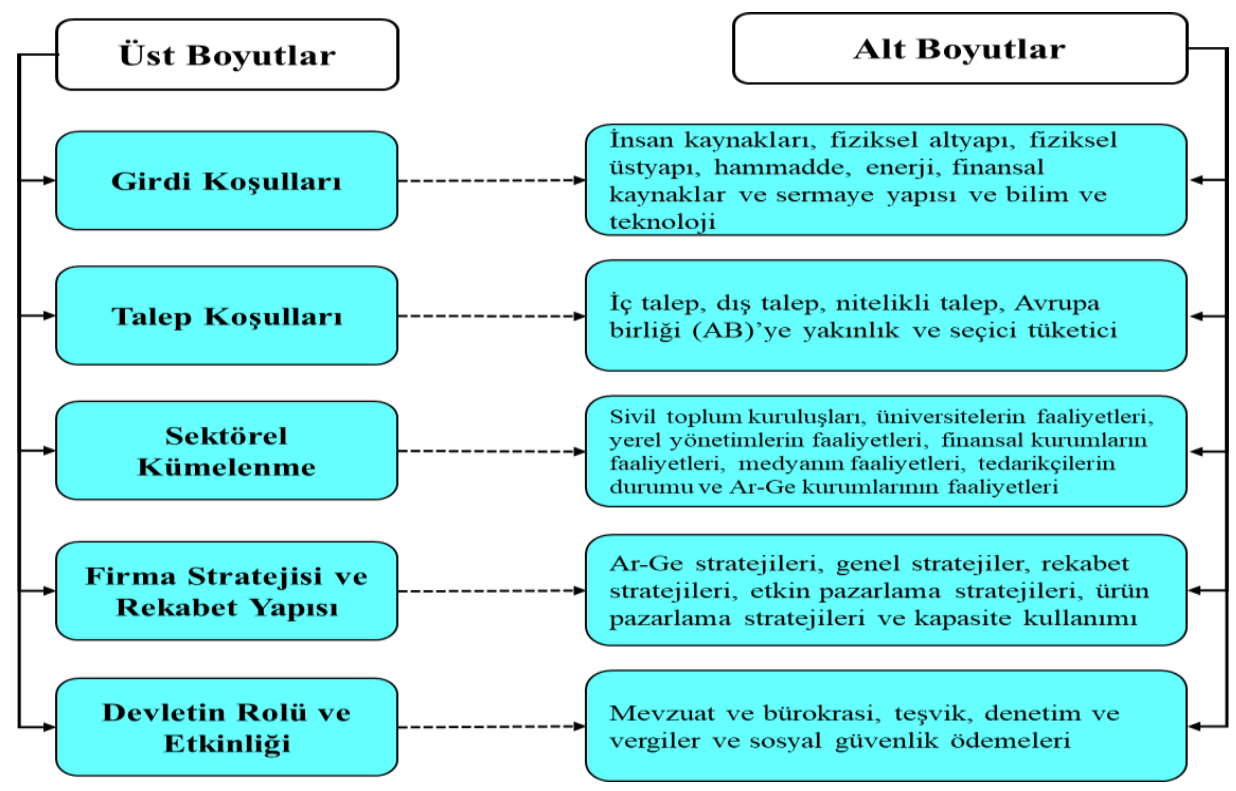

Derinlemesine mülakat yöntemi, sektörle ilişkili ve sektörün içinde önderlik rolü üstlenen kişilerle gerçekleştirilmiştir. Yönlendirici olmaktan kaçınmak ve görüşmecinin yönlendirici ve eksik bilgi vermesine yol açmamak için mülakatlar sohbet havasında ve soru yanıt şeklinde gerçekleştirilmiştir. Araştırmada müracaat edilen diğer birincil veri toplama tekniği olan anket yöntemi 
hızlı, sistematik ve güvenilir veri toplanmasını sağlayan bir veri toplama aracıdır. Anket formunda yer alan sorular yapılandırılmış sorular şeklinde hazırlanmıştır. Anketler katılımcılarla yüz yüze görüşülerek uygulanmıştır.

Çalışmanın son veri toplama tekniği olan uzman görüşü tekniğinde ise genel bir değerlendirme yapılmış ve sektöre yönelik öneriler alınmıştır. Görüşmeler araştırmacı ve uzmanların birebir görüşmeleri ile gerçekleştirilmiştir. Toplanan veriler içerik analizi ile analiz edilmiş ve mülakat ve anket verilerinin sonuçları ile karşılaştırılmıştır.

\section{Verilerin Analiz Yöntemi}

Porter'in Elmas Modeli, GETAT sektörünün rekabetçilik pozisyonunu analiz etmek için araç olarak kullanılmıştır. Uygulamada sektöre dair değişkenler ve değişkenlere ilişkin alt boyutlar elmas modelinin faktörleri 1şı̆̆ında incelenmiştir.

Çalışmanın değişkenlerinin her biri veri toplama tekniklerinden elde edilen veriler 1şı̆̆gnda tek dereceli olarak nitel analizde [0-100] ve nicel analizde [1-5] aralıklarında beş kategoride değerlendirilmiştir (Eraslan vd., 2007, s. 211: Bulu vd., 2006, s. 57). Bu kapsamda anket, mülakat ve uzman görüşü teknikleri ile elde edilen verilerin analiz sonucu ortaya çıkan rekabetçilik düzeyleri karşılaştırmalı bir şekilde değerlendirilmiş ve bu değerlendirme sonucunda da ortalama rekabetçilik düzeyleri tek tek modele yerleştirilmiştir.

Tablo 4: Veri Analizine Yönelik Oluşturulmuş Rekabetçilik Pozisyonlarının Aralık Değerleri

\begin{tabular}{|c|c|c|c|c|}
\hline & $\begin{array}{c}\text { Nitel- Derinlemesine } \\
\text { Mülakat/ 100 Üzerinden }\end{array}$ & $\begin{array}{c}\text { Nitel- Uzman } \\
\text { Görüşu/ 100 } \\
\text { Üzerinden }\end{array}$ & $\begin{array}{c}\text { Nicel- Anket/ } \\
\text { 5 Üzerinden }\end{array}$ & $\begin{array}{c}\text { Değerlerin Denk Geldiği } \\
\text { Rekabetçilik Düzeyleri }\end{array}$ \\
\hline \multirow{4}{*}{$\begin{array}{c}\text { Aralıklı } \\
\text { Değerler }\end{array}$} & 0 & 0 & 1 & Düşük/d \\
\cline { 2 - 5 } & $0-25$ & $0-25$ & $1-2$ & Düşük-Orta/ do \\
\cline { 2 - 5 } & $26-50$ & $26-50$ & $2-3$ & Orta/ o \\
\cline { 2 - 5 } & $51-75$ & $51-75$ & $3-4$ & Orta-Yüksek/ oy \\
\cline { 2 - 5 } & $76-100$ & $76-100$ & $4-5$ & Yüksek/y \\
\hline
\end{tabular}

Modelde yüksek "y" ile, orta-yüksek "oy" ile, orta "o" ile, düşük-orta "do" ile ve düşük "d" ile sembolleștirilmiştir. Değişkenlerin her birinin mevcut durumları değerlendirilmiştir. Bütün değerlendirmeler yapıldıktan sonra veriler normalize edilerek sektörün rekabetçilik seviyesi tespit edilmiştir. Nitelde 100 , nicelde ise 5 en yükssek rekabetçilik düzeyini temsil ederken sayı 0'a (nitel) ve 1'e (nicel) yaklaştıkça rekabet düzeyi düşüş gösterir. Düzeyler, uzman katılımcıların uluslararası karşılaştırma yapmaları ile her bir değişken ayrı ayrı 100 üzerinden puanlandırılarak belirlenmiştir. Değişkenlerin her birinin mevcut durumları değerlendirilmiştir. Örneğin, Ar-Ge alt değişkeni firma stratejisi ve rekabet yapısı faktörü için çok büyük öneme sahiptir; dolayısıyla mevcut durumu dünya ölçeğinde düşünüldüğünde, orta seviyeli olarak tespit edildiği için 2-3 aralığında değer almıştır. Sonuç olarak Ar-Ge değişkeninin değeri katılımcıların 
değerlendirmelerinin ortalaması olarak 2.80 tespit edilmiştir. Bütün faktörlerin düzeyleri saptandıktan sonra, aynı metodoloji, sektörün rekabetçilik pozisyonunu ortaya çıkarmak için de tekrarlanmıştır. Elde edilen nitel veriler içerik analizi ile analiz edilmiş ve daha sonra analiz edilen veriler tematik kodlama tekniği ile deşifre edilmiştir. Kullanılan tematik kodlama analizi jenerik bir yaklaşım olarak sunulmuştur. Nitel veri analizinde öncelikle teoriden yararlanılmış daha sonra yukarıda belirtildiği gibi veriler kodlanmış, temalar bulunmuş, veriler düzenlenip tanımlanmış ve son olarak bulgular yorumlanmıştır. Toplanan verilerin analizini kolaylaştırmak adına Microsoft Office $\subset$ uygulamaları olan Word ve Excel programları kullanılmıştır. Bu noktada mülakat sonuçlarını analiz için öncelikle kodlama sistemi oluşturulmuştur. Daha sonra bu kodlamalar ayrı başlıklar şeklinde değerlendirilmiş ve her bir kod başlığına göre temalar bulunmuştur. Bu şekilde kodların bir bütün içinde tek anlam ifade etmesi sağlanmıştır. Anket uygulaması ise GETAT öğrenci topluluğu ve ilgili sağlık ve akademik personeline uygulanmıştır. 5'li likert tipi anket kullanılmış ve likert ölçeği, kolaylığı nedeni ile tercih edilmiştir (Büyüköztürk, 2016, ss. 129-130). Katılımcılardan önermelerle ilgili görüşlerini, çok yüksekten çok düşüğe doğru sıralanan seçeneklerle belirtilmesi istenmiştir. Bu bağlamda sektörün genel rekabetçilik düzeyini ortaya çıkarmak için ölçeğe ilişkin ortalamalar dikkate alınmış ve likert tipine verilen cevaplar önemsenmiştir. Anket verileri SPSS 21 paket programı ile analiz edilmiştir. Ölçeğe ilişkin güvenilirlik analizi yapılmış ve ölçeğin güvenilirlik katsayısı 0.936 yani güvenilir düzeyde gerçekleşmiştir. Daha sonra ölçeğe ilişkin normal dağılıma uygunluk, betimleyici istatistik testleri (frekans- ortaya çıkma sıklı̆̆ı), yüzde, medyan, mod, standart sapma, varyans ve çapraz tablolar (Field, 2018, s. 140), T testi ve Doğrulayıcı Faktör Analizleri (DFA) yapılmıştır. Anket verilerinin analiz edilmesi ile bu testlere ilişkin sonuçlar mülakat ve uzman görüşü sonuçları ile karşılaştırılmıştır. $\mathrm{Bu}$ analizler elde edilen verilerin genel durumları hakkında fikir verme açısından önem taşımaktadır.

\section{DÜZCE İLİ GETAT SEKTÖRÜNÜN ELMAS MODELİ İLE ANALİİ}

Birincil ve ikincil veri toplama teknikleri kullanılarak elde edilen veriler, yukarıda adı geçen önem derecelerine (d-do-o-oy-y) göre değerlendirilerek alt değişkenler Şekil 3'te görüldüğü üzere modele yerleştirilmiştir. Bu bağlamda değerlendirildiğinde, Düzce ili GETAT sektörünün uluslararası rekabetçilik düzeyi düşük-orta şeklinde belirlenmiştir. 
Şekil 3: GETAT Sektörü Uluslararası Rekabetçilik Düzeyi

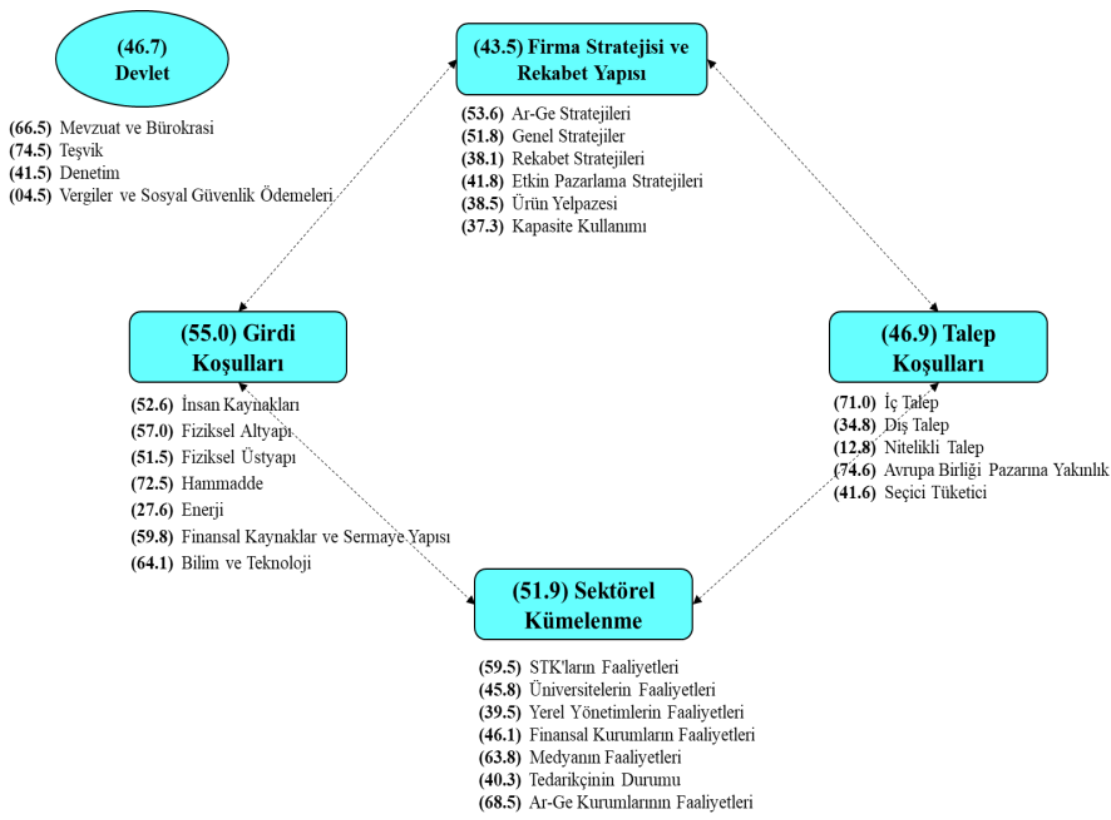

\section{Girdi Koşulları}

İnsan kaynaklarl: Herhangi bir sektörün insan kaynağını oluşturmada hem ulusal hem de yerel hükümetler büyük rol oynamaktadırlar. Porter girdi koşulları açısından eğitimli insan kaynağının rekabet gücünü elde etmede yüksek kalitede fayda sağladığını açıklamaktadır (Porter, 1998, s. 89). Önceleri fiziki sermayenin rekabet avantajı sağlamadaki önemine vurgu yapılmış ve hatta kalkınmanın en büyük itici gücü olduğu ileri sürülmüştür. Nitekim ilerleyen zamanlarda bu düşünce yerini tamamen insan sermayesine bırakmıştır. Fiziki sermaye ne kadar iyi olursa olsun eğer bununla harmanlanmış nitelikli bir insan gücü yoksa rekabet edebilecek güce de erişmek zor, hatta olanaksız olacaktır (Kılıç, 2014, s. 421). GETAT sektörüne yönelik yeteri kadar insan kaynağının olduğu ancak bu insan kaynağının niteliksiz oluşu göze çarpmaktadır. Önem verilmesi gereken temel noktalardan bir tanesi, mevcuttaki insan kaynağının profesyonelleştirilmesinin sağlanmasıdır.

Fiziksel Altyapı: Sektörel verimlilik düzeyinin artırılmasına etki eden temel unsurlardan bir tanesi altyapının durumudur. Altyapıya yönelik kamu veya kamu dışı harcamaları bir sektörün verimliliğini artırabilmektedir. Bu bağlamda Porter, bir sektörün ulusal veya uluslararası pazarlarda rekabet edebilmesi için, altyapı koşullarının yüksek miktarda etkili bir değişken olduğunu açıkça belirtmiştir. $\mathrm{Bu}$ altyapının sağlanması neticesinde güçlü bir rekabet potansiyeli ortaya çıkmış 
olacak ve sektör gelişime daha çok açık olacaktır (Porter, 1991, s. 112; Porter, 1998, s. 83). Sektörün yasal mevzuatlarla desteklenmesi yeni bir aşama olduğu için altyapı koşulları henüz tam anlamıyla düzenlenememiştir. Gerekli altyapının sağlanması bağlamında stratejik bölgeler seçilmesi ve ihtiyaç duyulan yapıların inşa edilmesi için son derece hassas davranılması gerektiğine dikkat çekilmiştir. Bu açıdan da altyapı çalışmalarında öncelik verilmesi gereken konuların Ar-Ge ve bilim olduğu ön plana çıkmaktadır. Çünkü insan sağlığına verilen değerin ancak bilimsel altyapı ile güçleneceği modern tıp anlayışının temel unsurudur.

Fiziksel Üstyapı: Üstyapı unsurları; altyapının tamamlayıcısı olarak planlanan ve inşa edilen ve kendileri üzerinden değer yaratılan fiziksel yapılardır (DAP, 2016, s. 86). Ancak sektörün altyapı koşullarının tamamlanmamış olması üstyapıda da sorunlar teşkil etmektedir. Oldukça düzensiz olduğu belirtilen şehir yapılanması, gerekli üstyapı koşullarını da olumsuz etkilemiştir. Nitekim GETAT merkezine yönlendirebilecek yönlendirme levhalarının bile olmaması üstyapıdaki eksikliğin büyüklüğünü ortaya koymaktadır.

Hammadde: GETAT sektöründe hammadde kaynakları oldukça çeşitlilik göstermektedir. Örneğin ozon uygulaması için patlayıcı olan bir (kokulu katı veya sıvı halde olan) bir molekül (Di Paolo vd., 2004, s. 1; Tütüncü ve Etiler, 2017, s. 80), akupunkturda iğneleme yöntemi ile deri altına verilen basınç (TTB, 2017, s. 20), apiterapide bal, balmumu, arı poleni vs. (Öztürk ve Selçuk, 2016, s. 125; Aslan, 2016, s. 4) şeklinde sıralanabilir. Ancak geleneksel tıbbın en çok kullanılan ve en çok bilinen yöntemleri bitkisel yöntemler olup en fazla hammadde de bitkisel kökenli olmaktadır. Bu açıdan da sektörün en güçlü yönlerinden bir tanesi bölgenin hammadde bakımından zengin oluşudur. Fakat hammaddenin işlenip uygun standartlara getirilmesi için profesyonel insan kaynağının yanı sıra Ar-Ge imkânlarının ve bilimsel altyapının da gerekliliğini ortaya koymaktadır.

Enerji: Artan enerji gereksinimi ve bunun ortaya çıkardığı sorunlar; ekonomiyi, çevreyi ve sosyal yaşamı yani sürdürülebilir kalkınmanın her safhasını olumlu ve/ veya olumsuz bir şekilde etkilemiş ve etkilemeye devam etmektedir. Günümüz devletleri için ekonomik ve politik bakımdan enerji ihtiyacı stratejik öneme sahip bir unsur haline dönüşmüştür. Nitekim günümüz uluslararası rekabetinin en önemli rekabet yarışından birini enerji oluşturmaktadır. $\mathrm{Bu}$ açıdan enerji kaynakları üzerindeki rekabetin stratejik bir öneme sahip olması uluslararası ilişkilerde yapıcı veya bozucu bir unsur olmasıdır (Akbaş ve Karadağ, 2010, s. 44). Ancak GETAT sektörü üzerindeki etkisi incelenecek olursa genel olarak bu sektörün yoğun bir enerji ihtiyacı olmadığı söylenebilir. Nitekim yapılmış görüşmelerde de enerji faktörünün çok ön plana çıkmadığı ve katılımcıların üzerinde durmaya gerek görmediği bir faktör olduğuna dikkat çekilmiştir.

Finansal Kaynaklar ve Sermaye Yapısı: GETAT sektörünün en büyük mali yatırımcısının devlet olduğu belirtilmiştir. Devletin sağlamış olduğu mali destekle, üniversite yapmış olduğu bilimsel çalışmalarla öncü bir rol oynamakta ve yerel yönetimlerin de katkıları ile bir bütünlük oluşturulmaktadır. Sektöre yapılan 
yatırımlarda en büyük rolü oynayanlar içinde Kalkınma Bakanlığı (Mülga), YÖK ve Düzce Üniversitesi gibi güçlü kurumlar yer almaktadır. İlk aşamada devlet 73 milyon TL ile bir yatırım gerçekleştirmiş ve çalışmaların hızlanmasını sağlamıştır. Bu noktada Ar-Ge ve bilimsel dayanak oluşturulması adına en ciddi çalışmalar Düzce Üniversitesi eli ile yürütülmekte ve bölgeye çekilen firmalara mentörlük yapılarak bir kümelenme oluşturulmaktadır. Bölgenin coğrafik yapısının da vermiş olduğu avantaj ve aynı zamanda sanayi olarak gelişim göstermiş olması devlet dışındaki özel kurumların da sektöre yatırım yapmasını sağlamıştır.

Bilim ve Teknoloji: Bilim için mazisi çok yeni olan bu sektörün teknolojik yeniliğe ihtiyaç duyduğu analiz edilmiştir. Sektörün bilimsel olabilmesi için akademik camianın eline bırakılması gerektiği aktarılmışır. Somut olarak daha fazla uygulama, araştırma ve ürün üretiminin yapılmasına ihtiyaç duyulmaktadır. GETAT ürünlerinin yüksek teknolojik girdi gerektirmediğine dikkat çekilmiş ve bu alanda daha çok emeğe ve zamana ihtiyaç duyulduğu belirtilmiştir. Çünkü GETAT sektöründe basit teknolojik altyapı ve basit tekniklerle ürün üretilebilmektedir. Spesifik bir hizmet sektörü olduğu için süreç bazlı bir teknoloji ile ilerleme göstermesi mümkündür.

\section{Talep Koşulları}

İç ve dlş talep: Düzce'nin coğrafik konumu hem iç hem de bir diş talep potansiyelinin oluşmasında en önemli etkenlerden birisi olmaktadır. Bu açıdan iç talep olarak belli bir potansiyeli olmakla birlikte bu potansiyelin bilgilendirilmesi gerektiği ve daha geniş kitlelere ulaşılması noktasında reklam ve tanıtım faaliyetlerine önem verilmesi gerektiği düşünülmektedir. Sektöre olan yerel talebe karşın dış talep potansiyeli henüz oluşmuş değildir. İnsan kaynağı, teknik donanım, hizmet genişliği, konaklama hizmetleri gibi birçok alandaki eksiklik dış talebe cevap verecek potansiyelin olmadığını göstermektedir. $\mathrm{Bu}$ açıdan sektörün öncelikli olarak büyüme aşamasını gerçekleştirmiş olması gerekmektedir.

Nitelikli talep: Belli bir endüstrideki talebin nitelik düzeyi talep koşulları ile yakından ilişkilidir. Bu aşamada müşterinin seçiciliği önemli bir role sahip olup nitelik açısından yurt içi talebin değerlenip yurt içinde rekabetin büyümesini sağlamaktadır (Suci, 2015, s. 65). GETAT sektörünün genel çerçevesi oturmadığından dolayı sektöre yönelik nitelikli bir talebin olmadığının da altını çizmektedir. Ancak var olan nitelikli talebin de yasal olmadığı ve bilimsel temel dayanağı olmadan önceki uygulamalardan yararlanıp bu konuda bilinç düzeyinin biraz yüksek olan kişilerden olduğu belirtilmiştir. Ancak bu nitelikli talebin uluslararası pazarlarda rekabet edebilecek düzeyde bir yenilik yaptıracak nitelikte olmadığına dikkat çekilmektedir.

Avrupa Birliği pazarına yakınlı: Türkiye, Uzakdoğu rakiplerine oranla AB pazarına daha yakın bir mesafede yer alması ile avantajlı konumdadır. Ortak ürün üretme kabiliyeti, vasıflı işgücü ve pazara malları sürme süresi $\mathrm{AB}$ pazarının farklı boyutlarda değerlendirildiğini göstermektedir. Türkiye bu yakınlık faktörü 
1şığında $\mathrm{AB}$ tarafından orta maliyetli olarak tanımlanmaktadır (Eraslan vd., 2008b, ss. 290-291). Türkiye'nin AB pazarına yakınlığı birçok sektörün yanı sıra GETAT sektörünü de olumlu olarak etkilediği bilinmektedir. Özellikle AB pazarının müşteri portföyünün yüksek alım gücü sektörlerin gelişimlerini olumlu etkilemektedir.

Seçici tüketici: Sektörün girişimci ve yenilikçi olması seçici tüketicinin davranışından etkilenmektedir. Çünkü seçici bir tüketici kitlesi, kaliteli üretimi ödüllendirirken diğer taraftan kalitesiz üretimi de cezalandırarak sektörü ileriye taşıma özelliğine sahiptir (Bulu vd., 2006, s. 59). Sektörel analiz doğrultusunda tüketicinin seçici olması beklentisi olmadığı belirlenmiştir. Çünkü sektör kendine yer edinmemiş ve daha yeni yeni filizlenmeye başlamıştır ki sektör de ürün bakımından seçici olmayı gerektirmeyen bir sektördür.

\section{Sektörel Kümelenme}

Sivil Toplum Kuruluşlarının Faaliyetleri (STK): Devlet dışı ve pazar dışı oyuncular olan STK'lar, sivil toplumu temsil eden ve günümüzde giderek daha rekabetçi ortamda faaliyet gösteren üçüncü bir sektör olmuştur (Schwenger vd., 2014, ss. 11-12). STK'ların rekabetçi bir ortamda büyük etkisinin olması dikkate alınınca, katılımcıların görüşlerinden elde edilen bilgilere göre GETAT sektörünün bu anlamda bir gelişim göstermediği ve bu yapılanmanın çok yavaş oluştuğu anlaşılmaktadır. Sivil örgütlerin az bir etkisi olmakla sadece yerelde faaliyette bulunduğu yani iç dinamiklerle işbirliğine gidebildiği aktarılmıştır.

Üniversitelerin Faaliyetleri: Küresel ekonomik ortamda rekabet avantajı elde etmek ve bu rekabeti devam ettirmenin temel yapı taşını bilgi ve teknolojiyi üreten ve aynı zamanda kullanabilen bireylerin yetiştirilmesine bağlıdır. Bunu başarabilen üniversiteler hem ekonomik kalkınma hem de küresel rekabetin dinamikleri olarak, ülkelerin geleceklerine yön verebilmektedirler (Yıldız ve Talih, 211, ss. 271-272). Bu anlamda üniversite GETAT sektöründe pilot üniversite olarak seçilmiş ve aynı zamanda ana teması GETAT ihtisaslaşma konusunu oluşturmuştur. GETAT sektöründeki bütün süreçlerde ana oyuncu üniversite olmakta ve yerelde faaliyette bulunacak firmaların arasındaki tek aracı konumundadır. Aslında sektörde mihmandarlık görevini üstlenmiş ve esas oyuncu üniversitedir.

Yerel Yönetimlerin Faaliyetleri: Yerel yönetimler bölgesel ve ekonomik kalkınmada önemli bir etkiye sahiptir. Yerel ekonomiler arasındaki rekabet, yerel ekonomilerdeki gelişme performansını etkilemektedir. $\mathrm{Bu}$ durum merkezi yönetimlerin bölgesel kalkınma üzerindeki tekelcilik rolünü de ortadan kaldırmaktadır (Bilgin, 2002, s. 316). Yerel yönetimlerin GETAT sektörü üzerindeki faaliyetleri incelendiğinde; yerelde üniversite, belediye, valilik gibi kurumların toplantı veya konferanslarda bir araya gelerek alana katkı sağladığı ve bunun yerelde halk ve ilgili sektör bileșenleri ile paylaşıldığı yönündedir. Aslında yerel yönetimlerin sadece manevi desteğinden söz edilebilir. 
Finansal Kurumların Faaliyetleri: Firmaların sahip oldukları finansal kaynaklarla, finansal ihtiyaçların karşılanması rekabet gücü elde etmede önem arz etmektedir (Bakımlı, 2011, s. 32). GETAT sektöründe de devlet desteğinden başka bir firmanın katkı sağlamadığı görülmüştür. Finans kurumlarının işlevsizliği ön plana çıkmıştır.

Medyanın Faaliyetleri: Sektöreler veya işletmeler medya araçlarını etkin kullanarak tüketicilerin davranışlarına müdahale eden unsurları daha verimli ve etkin kullanıp rekabet gücü elde edebilmektedirler. Bu açıdan rakiplerine karşı rekabet üstünlüğü elde edebilmektedirler (Toksarı vd., 2014, s. 1). Sektörde yaygınlık göstermemiş basın faaliyetlerinin olduğu değerlendirilmiştir. Ancak en etkili çalışmanın ulusal basında sesini duyurmaya başlaması ve bunun yankılarını arttıracak politika olarak bir medya hizmetinin satın alınmasıdır.

Tedarikçilerin Durumu: Rekabet avantajı, bir sektöre yenilikçi ve ucuz bir girdi sağlayan tedarikçi zinciri ile daha da güçlü olmaktadır (Eraslan vd., 2007, s. 209). Karmaşık bir tedarikçi yapısına sahip olan GETAT sektörü, güçlü bir yapıya sahip olabilmesi için sektörün kurumsallaşma gerekliliği ortaya çıkmıştır.

Ar-Ge Kurumlarının Faaliyetleri: Ulusların ekonomik gelişmelerinde etkili bir araç olan Ar-Ge faaliyetleri katma değeri yüksek ürünlerin üretimini sağlayıp ihracata yönelik bir akış sağlayabilmektedir (Suci, 2015, s. 27). Sektörün en büyük oyuncusu olan üniversitenin gücü ile teknopark bünyesinde kurulan iki adet özel firmanın Ar-Ge çalışmalarının ve 14 farklı firma ile de Ar-Ge ve ortak yatırım yapma konusunda anlaşmaların olduğu analiz edilmiştir.

\section{Firma Stratejisi ve Rekabet Yapısı}

Ar-Ge stratejileri: Stratejik bir Ar-Ge faaliyetinin varlığından söz etmek güçtür. Bu yönde yapılan açıklamaların, sektörde Ar-Ge çalışmalarının yazılı bir doküman olmadan plansız yapıldığg yönündedir. Ancak bilgi ve birikim anlamında akademik bir altyapısı olan üniversitenin sektöre yönelik çalışmalar yapması sektöre avantaj sağlayabilmektedir. Sektörün arkasında akademik bilgi birikiminin varlığı sektörü kalkındırma anlamında güçlendirmekte ve piyasada kendine yer edinebilecek bir güç verebilmektedir.

Genel stratejiler: Öne çıkan anlayış, GETAT sektörünün merkeziyetçi bir yönetim anlayışı yerine bütün bürokratik süreçlerden arındırılmış ve kendi bünyesinde özerk bir şirket şeklinde yönetilmesidir. Sonuç olarak sektör, özerk olarak gelir elde eden, borçlanan ve yatırım yapan bir yapı ile kendi kendini sürdürülebilir hale getirmelidir.

Rekabet stratejileri: Porter firmaların maliyet liderliği, farklılaşma ve odaklanma stratejileri şeklinde üç farklı rekabet stratejisi ile rekabet avantajı elde edebileceğini belirtmiştir. Bir işletmenin ortalamanın üzerinde performans sergileyebilmesi için bu üç stratejiden en az bir tanesine odaklanması gereklidir 
(Eraslan, 2014, s. 42). GETAT sektörünün bunu gerçekleştirmiş bir düzeyde olmadığ 1 tespit edilmiştir.

Etkin pazarlama stratejileri: Etkili bir pazarlama stratejisinde en düşük fiyatla en etkili sonuçların elde edilmesi sağlanmalıdır. $\mathrm{Bu}$ açıdan pazarın farklı katmanlarında tüketicilerin istek ve ihtiyaçlarının etkili bir pazarlama stratejisi ile kaliteli ve iyi şartlarda belirtilmesi gerekmektedir (Buckley vd., 2010, s. 192). Üretilen ve üretilecek olan ürünlerin pazarlamaya ihtiyaç duyduğu değerlendirilmiştir.

Ürün yelpazesi: Pazar bölümlerinin çoğuna geniş ürün yelpazesi ile ulaşılabilir. Örneğin İtalya, ürün farklılaştırarak ürün yelpazesini genişletmiş ve bu sayede küresel arenada rekabet gücü elde etmiştir. Ürün yelpazesinin fazla olması ile işletmeler maliyet liderliğini elde edebilir ki bu da rekabet üstünlüğü sağlar (Eraslan vd., 2008, s. 295). 67 çeşit ürün üretiminin olduğu belirtilmiştir. Ancak bu ürünlerin ilgili pazara uygun (medikalize) edilmesi gerekliliği söz konudur.

Kapasite kullanımı: GETAT sektöründe kitlesel ve seri bir üretim süreci söz konusu değildir. Bu aşamada sektör sadece ön çalışmalarla sektörel faaliyetleri sürdürmektedir. Kapasite kullanım oranının belirlenmesi konusunda da somut çıktıların olması gerekliliği ortaya çıkmıştır.

\section{Devletin Rolü ve Etkinliği}

Mevzuat ve Bürokrasi: Sektörel hizmetlerin yasalaştırılma kapsamı özellikle 2014 yllında genişletilmiştir. Ancak uygulamaya ihtiyaç duyulan bir mevzuat yapısı söz konusudur.

Teşvik: GETAT ihtisaslaşma konusu ile üst merciler (Cumhurbaşkanlığı gibi) tarafından desteklenmektedir. Buna bağlı olarak hem maddi hem de manevi olarak sektörün ihtiyaç duyduğu kaynaklar temin edilebilmektedir. Devlet desteği ve teşviklerinin olması sektörün rekabet edebilirliğinde büyük oranda avantaj sağlamaktadır.

Denetim: Sağlık Bakanlığ1 tarafından denetimlerin yapıldığ 1 ancak bu denetimlerin yetersiz olduğu anlaşılmıştır. GETAT yasa dışı uygulamalarının yüksek düzeyde oluşu ve buna herhangi bir müdahalenin olmayışı sektörün önünde en büyük engel olarak görülmektedir.

Sosyal Güvenlik Ödemeleri: Modern tıpta olduğu gibi GETAT uygulamaları ve tıbbi ürünleri geri ödeme kapsamında yer almamaktadır. Ancak gerek hastalar gerekse de uygulayıcıların bu yönde taleplerinin olduğu belirtilebilir. Nitekim geri ödeme kapsamına alınması ile daha çok tercih edileceği ve bu yönde daha çok çalışmanın yapılacağını teşvik edeceği anlaşılmaktadır.

\section{Sonuç ve Öneriler}

Düzce ili GETAT sektörünün rekabetçilik seviyesi, elmas modeli ile yapılan analiz sonucu, 48.8 yani orta seviyede tespit edilmiştir. Bu sonuca, 
incelenen dört ana değişken ve devletin, sektörün rekabetçilik düzeyine yaptığ 1 katkı düzeyleri dikkate alınarak ulaşı1mıştır.

Girdi koşullarında toplamda 7 alt değişken değerlendirilmiştir. $\mathrm{Bu}$ alt değişkenlere göre yapılmış olan analizler sonucunda insan kaynakları, fiziksel altyapı ve fiziksel üstyapı değişkenlerinin rekabet edebilecek düzeyde olmadığg 1 tespit edilmiştir. Hammadde, finansal kaynaklar ve sermaye yapısı ve bilim ve teknoloji alt değişkenlerinin ise belli bir potansiyele sahip olduğu ancak bu potansiyelin etkin kullanabilecek herhangi bir yapının var olmadığı ortaya çıkmıştır. Diğer taraftan sektörün genel olarak düşük seviyede enerji ihtiyacının olması enerji alt değişkenine yönelik bir eksikliğin olmadığını göstermiştir.

Talep koşulları faktörüne bağlı olarak 4 alt değişken incelenmiştir. Talep değişkenlerine göre sektörün belli bir iç talebinin olduğu görülmüştür. Ancak dış talep açısından sektörün henüz hazır olmadığ1 sonucuna ulaşılmıştır. Var olan talebin nitelikliliği oldukça karmaşıktır. Tarih boyunca kullanılan yöntemler olmasına rağmen bilimsel altyapısı olmayan ve tecrübeye dayalı bir niteliğin olduğu, sonuçta da seçici bir tüketici kitlesinin olmadığı söylenebilir. Bu durum da sektörün gelişimini engellemektedir. Düzce coğrafik olarak AB pazarına yakınlığı ile avantajlıdır. Ancak bu avantajı kullanması için öncelikle GETAT uygulamaları Avrupa standartlarına çıkarılmalı ve profesyonel bir altyapı oluşturulmalıdır.

Sektörel kümelenme ana eksenine bakıldığında toplamda 7 alt değişkenle analiz edilmiştir. Sektörel kümelenmenin rekabetçilik seviyesi ve yeterliliği işletmelerin rekabetçilik avantajına doğrudan etki etmektedir. Küresel piyasalarda başarı göstermiş bir sektör, kendisi ile ilgili başka bir sektörü de küresel anlamda başarıya götürebilmektedir. Buna İtalya deri ve ayakkabı sektörü iyi bir örnek teşkil etmektedir. İtalya, deri ve ayakkabı sektöründe küresel başarı gösterirken bu sektörle ilgili olan iyi deri işleme makineleri sektöründe de başarı gösterir. Tedarikçi zincirinin rekabetçi oluşu, rekabet avantaj1 oluşturma noktasında bir sektöre ucuz ve yenilikçi girdi temini sağlar. Yenilikçilik ve bilgi alışverişi de birbiri ile yatay ve dikey ilişkide bulunan sektörlerle bilgi alışverişi ile olabilmektedir (Bulu vd., 2006, s. 55). Bu bağlamda sektörün en iyi faaliyet gösteren oyuncusu üniversite olarak öne çıkmıştır. Fakat sektörel kümelenmeye ilişkin bir yapılanmanın oluşmadığı sonucuna varılmıştır.

Firma stratejisi ve rekabet yapısı ekseni değerlendirildiğinde 6 tane alt değişkenin incelendiği ve diğer ana eksenlere göre en düşük rekabet gücüne sahip faktör olarak öne çıktı̆̆1 görülmüştür. Porter burada, firmaların örgüt yapılarını, yönetim tarzlarını, kuruluş biçimlerini ve ulusal rekabetçiliğini incelemiştir. Firmaların yönetim tarzları, rekabet yapısı açısından firmanın stratejisini doğrudan etkilerken, kültürlerin yönetim tarzı, fïrma ilişkileri, örgütsel yapısı vb. üzerinde olumlu veya olumsuz etkileri olmaktadır. Küresel rekabetçilik de ulusal rekabet yapısı ile yakından ilişkilidir. İç piyasada firmalar her ne kadar düşük rekabeti avantaj olarak görse bile, bölgesel rekabetin niteliği, firmaları yenilikçiliğe ve ekonomik olanakların ötesine geçmeye zorlayıp küresel pazarlarda rekabete hazır 
hale getirir (Bulu vd., 2006, s. 55). Bu doğrultuda incelendiği zaman Düzce İli GETAT sektörünün yapılanması ile yeterli yetkinliğe ulaşmamış olmakla birlikte, sektöre yönelik bir strateji de geliştirilmemiştir. Dolayısı ile stratejisi olmayan bir yapının rekabet edebilir gücünden söz etmek de olanaksızdır.

Devletin rolü ve etkinliği faktörü diğer dört faktörü dışarıdan dışsal bir faktör olarak etkilemekte ve avantaj oluşturmada dolaylı rol oynamaktadır. Diğer dört faktör üzerinden mevzuatları düzenleyerek, denetim mekanizması kurarak, vergi sitemini düzenleyerek ve tekel oluşumlarının önüne geçerek rekabet pozisyonuna etki edebilmektedir (Bulu vd., 2006, s. 55). Bu faktörün altında toplamda 4 tane değişken incelenmiştir. Bakıldığı zaman sektörün mevzuat altyapısı oluşturulmaya başlanmış ve ilk elden de devlet teşvikleri ile sektör kalkındırılmaya çalışılmıştır. Ancak denetim mekanizması eksikliği sektörün gelişimi önünde en büyük engel olarak ortaya çıkmıştır. Diğer taraftan mevzuatın uygulanmasındaki eksikliklerin varlığı ön plana çıkmıştır. Genel anlamda kontrolsüz ve denetim olmayan piyasa ile himayeye dayalı bir teşvik söz konusudur. Talepler doğrultusunda mevzuatın uygulanabilirliğinin artırılması, teşvik mekanizmasının genişletilmesi ve geri ödeme sisteminin geliştirilmesi sağlanmalıdır.

Sonuç olarak insanlarda beklenen yaşam süresinin uzaması ile paralel bir şekilde kişisel bakım ihtiyacı ve izleminin önem kazanması malign ve kronik hastalıklar, sağlık çalışanlarının hastalara yeteri kadar zaman ayıramamaları, konvansiyonel tıbbi ilaçlardaki yan etkilerinden uzak durma isteği gibi nedenler GETAT'a olan ilginin artmasını da tetiklemiş ve hatta gelecekte bu ilginin daha çok artacağı da tahmin edilmektedir (Ünal ve Dağdeviren, 2019, s. 5).

Günümüzde bölgesel kalkınma çalışmaları yaygın bir şekilde sektörler üzerinden icra edilmektedir. Diğer bir ifade ile bölgenin çekirdek yeteneğine uygun ve elverişli olan sektörün küresel rekabetçilik gücü (yukarıda adı geçen modeldeki alt değişkenlerin tamamı göz önüne alınarak) geliştirilerek yapılmaktadır. $\mathrm{Bu}$ bağlamda sektör bir lokomotif görevi görmektedir. Sektörün rekabetçilik gücünün artmas1 aynı zamanda ihracat, diğer bir manada ise gelirin artması anlamını taşımaktadır. Elde edilen dış gelirin bölgeye yansıması ile birlikte, bölgenin ekonomik kalkınma sürecinde iyileşmeler elde edilmektedir. Tabii bu sürece paralel olarak kümelenme yaklaşımının etkin bir şekilde kullanılması ise sektörel kalkınmanın gerçekleştirilmesinin etkinliğini yüksek düzeyde artırmaktadır.

$\mathrm{Bu}$ çalışmada da, GETAT sektörünün bölgesel kalkınmaya etkisi araştırılmıştır. $\mathrm{Bu}$ bağlamda, öncü (lider) sektör olarak ulusal düzeyde yerel kalkınma planına dâhil edilen GETAT sektörünün öncelikle küresel rekabetçilik gücü analiz edilmiştir. Analiz neticesinde, bölgenin kalkınmasında bir kaldıraç olarak görülen (öngörülen) sektörün rekabetçilik gücünün zayıf düzeyde olduğu ortaya çıkarılmıştır. Bununla birlikte bölgede önemli bir potansiyeli olan sektörün, rekabetçilikte öngörülen alt değişkenlerine yönelik yapılacak olan geliştirme ve iyileştirme çalışmaları ile orta, iyi ve yüksek düzeye yükseleceği beklenmektedir. 
Ancak bu süreç hemen olacak gibi algılanmamalıdır. Nitekim küresel örnekler göz önüne alındığında bu sürecin, orta ve uzun vadeli sektörel kümelenme geliştirme çalışmaları ile (bir master plana bağlı olarak) geliştirildiği ve etkin mekânsal planlama ile birlikte finansal kaynaklar ile desteklendiği müşahede edilmektedir. $\mathrm{Bu}$ açıdan değerlendirildiğinde GETAT sektörünün Düzce ilinde gelişmesi ve bölgesel kalkınmada öncü rolü oynayabilmesinin yegâne temeli, bir lider kurum ve kuruluş altında örgütlenmeye gidilerek, etkin kümelenme temelli geliştirme (cluster based regional development) programının uzun erimli bir proje dâhilinde başlatılarak sabır ve gayretle hayata geçirilmesi öngörülmektedir.

\section{KAYNAKÇA}

Ahuja, V., ve Ahuja, A. (2011). Apitherapy-a sweet approach to dental diseases. Part II: Propolis. Journal of Advanced Oral Research, 2(2), 1-8.

Akbaş, Z. ve Karadağ, A. (2010). Enerji kaynaklarının stratejik önemi uluslararası güvenliğe ve Türk diş politikasına yansımaları ve Türkiye açısından firsatlar ve tehditler. (Editör: İsmail Hakk1 Eraslan). Sürdürülebilir rekabet avantajı elde etmede enerji sektörü: sektörel stratejiler ve uygulamalar. İstanbul: Mos Ajans, 43-65.

Al-Faris, E. A., Al-Rowais, N., Mohamed, A. G., Al-Rukban, M. O., Al-Kurdi, A., Balla Al-Noor, M. A., ... ve Sheikh, A. (2008). Prevalence and pattern of alternative medicine use: the results of a household survey. Annals of Saudi Medicine, 28(1), 4-10.

Arslan, M., Şahne, B. S., ve Şar, S. (2013). Alternatif bir tedavi sistemi: homeopati. Journal of Literature Pharmacy Sciences, 2(2), 47-54.

Aslan, R. (2016). Hekimlikte alternatif ve tamamlayıcı tıbbi yaklaşımlar. Kocatepe Veteriner Dergisi, 9(4), 363-371.

Ayhan, H., ve Mollahaliloğlu, S. (2018). T1bbi sülük tedavisi: hirudoterapi. Ankara Medical Journal, 18(1), 141-148.

Bilgin, M. (2002). Yerel yönetimlerin bölgesel kalkınmadaki etkinliği: göller bölgesi uygulaması. Süleyman Demirel Üniversitesi Íktisadi ve İdari Bilimler Fakültesi Dergisi, 7(2), 313-330.

Bodeker, G. ve Burford, G., (2007). Traditional, complementary an alternative medicine: policy and public health perspectives. Singapore: Mainland Press.

Buckley, P.J., Pass, C.L. ve Prescott, K. (2010). Measures of international competitiveness: a critical survey. Journal of Marketing Management, 4(2), 175200. 
Bulu, M., Eraslan, İ. H., ve Şahin, Ö. (2004). Elmas (Diamond) modeli ile Ankara bilişim kümelenmesi rekabet analizi. 3. Ulusal Bilgi, Ekonomi ve Yönetim Kongresi, 25-26, Kasım, Eskişehir.

Bulu, M., Eraslan, İ.H., ve Barca, M. (2007). Türk gida sektörünün uluslararası rekabetçilik düzeyinin analizi. Afyon Kocatepe Üniversitesi İ̈BF Dergisi, 9(1), 311-335.

Bulu, M., Eraslan, İ.H., ve Kaya, H. (2006). Türk elektronik sektörünün rekabetçilik analizi. Istanbul Ticaret Üniversitesi Sosyal Bilimler Dergisi, (19), 4966 .

Covington, H., ve Crosby, C. (1997). Music therapy as a nursing intervention. Journal of Psychosocial Nursing and Mental Health Services, 35(3), 34-37.

Creswell, J.W. ve Clark, V.L.P. (2011). Karma yöntem desen seçimi. (Çeviri Editörleri: Yüksel Dede ve Selçuk Beşir Demir, 2015). Karma yöntem araştırmaları: tasarımı ve yürütülmesi. Anı Yayıncılık: Ankara.

Çelik Yılmaz, A. (2017). Bel ve boyun fittğg olan hastaların ameliyat öncesi ăgrı gidermede kullandıkları tamamlayıcı yaklaşımlar. Yüksek Lisans Tezi, İstanbul Üniversitesi Sosyal Bilimler Enstitüsü, İstanbul.

DAP (Doğu Anadolu Projesi). (2016). DAP bölgesi büyükbaş ve küçükbaş hayvancılık sektörünün uluslararası rekabetçilik analizi raporu. (Rapor No: yok). Erzurum. T.C. Kalkınma Bakanlığı DAP Bölge Kalkınma İdaresi Başkanlığı.

Debas, H. T., Laxminarayan, R., ve Straus, S. E. (2006). Complementary and alternative medicine. Disease Control Priorities in Developing Countries, 12811291.

Di Paolo, N., Bocci, V., ve Gaggiotti, E. (2004). Ozone therapy. The International Journal of Artificial Organs, 27(3), 168-175.

EFCAM (European Federation for Complementary and Alternative Medicine). (2019). Research. http://www.efcam.eu/, (Erişim Tarihi: 03.01.2020)

El-Dahshan, N. A., Ismail, M. A., ve Metwally, A. S. (2015). Use of complementary and alternative medicine among families having patients with chronic diseases: el-mahsama village-1smailia governorate. Therapy, 6, 139.

Eraslan, I. H. (2008a). The Effects of Competitive strategies on firm performance: a study in Turkish textile and apparel industry considering the mediating role of value chain activities. Unpublished Doctoral Dissertation. Boğaziçi University Social Sciences Institute, İstanbul.

Eraslan, İ. H., ve Dönmez, C. Ç. (2017). Endüstriyel kümelenme uygulamalarının Türkiye genelinde incelenmesi: sanayi, tarım ve hizmet sektörleri açısından bir değerlendirme. Elektronik Sosyal Bilimler Dergisi, 16(61), 325-368. 
Eraslan, İ. H. (2014). Rekabet stratejileri kararlarının firmaların finansal performansı üzerindeki etkileri: stratejik düşünce perspektifinden bir analiz. Bartın Üniversitesi İktisadi ve İdari Bilimler Fakültesi Dergisi. 5(10), 21-71.

Eraslan, İ. H., Bakan, İ., ve Helvacioğlu Kuyucu, A. D. (2008b). Türk tekstil ve hazırgiyim sektörünün uluslararası rekabetçilik düzeyinin analizi. Ístanbul Ticaret Üniversitesi Sosyal Bilimler Dergisi, (13), 265-300.

Eraslan, İ. H., Karataş, A., ve Kaya, H. (2007). Türk plastik sektörünün rekabetçilik analizi. İstanbul Ticaret Üniversitesi Sosyal Bilimler Dergisi, (11), 203-219.

Erci, B. (2007). Attitudes towards holistic complementary and alternative medicine: a sample of healthy people in Turkey. Journal of Clinical Nursing, 16(4), 761-768.

Erel, Ö.,ve Erel, K. V. (2014). Hipnoz ve genel tıp pratiğinde kullanımı. Türkiye Klinikleri Family Medicine-Special Topics, 5(4), 46-48.

Ernst, E. (2008). Complementary medicine in Germany.

Furat, S. (2019). Düzce ilinin geleneksel ve tamamlayıcı tıp (GETAT) sektörünün uluslararası rekabetçilik analizi. Yüksek Lisans Tezi. Düzce Üniversitesi Sosyal Bilimler Enstitüsü, Düzce.

Field, A. (2018). Discovering statistics using IBM SPSS statistics. (Fifth Edition). London: SAGE Publications Ltd.

Gençel, Ö. (2006). Müzikle tedavi. Kastamonu Eğitim Dergisi, 14(2), 697-706.

Getatportal, (2020). Geleneksel ve Tamamlayıcı Tıp Daire Başkanlığı. https://getatportal.saglik.gov.tr/, (Erişim Tarihi: 08.01.2020).

Grammaticos, P. C., ve Diamantis, A. (2008). Useful known and unknown views of the father of modern medicine, hippocrates and his teacher democritus. Hell J Nucl Med, 11(1), 2-4.

Hori, S., Mihaylov, I., Vasconcelos, J. C., ve McCoubrie, M. (2008). Patterns of complementary and alternative medicine use amongst outpatients in Tokyo, Japan. BMC Complementary and Alternative Medicine, 8(1), 14.

Iş1k, M., ve Aksoy, N.A. (2012). Tıbbî sülük tedavisi (hirudoterapi) ve hacamat. Sağllk Düşüncesi ve Tip Kültürü Dergisi, 22, 80-84. http://www.sdplatform.com/Dergi/602/Tibb-suluk-tedavisi-hirudoterapi-veHacamat.aspx, (Erişim Tarihi: 07.01.2020)

Jin, B., ve Moon, H. C. (2006). The diamond approach to the competitiveness of korea's apparel industry: Michael Porter and beyond. Journal of Fashion Marketing and Management: An International Journal, 10(2), 195-208. 
Johnson, S. B., Park, H. S., Gross, C. P., ve James, B. Y. (2018). Complementary medicine, refusal of conventional cancer therapy, and survival among patients with curable cancers. JAMA Oncology, 4(10), 1375-1381.

Karahancı, O. N., Öztoprak, Ü. Y., Ersoy, M., Zeybek Ünsal, Ç., Hayırlıdağ, M., ve Örnek Büken, N. (2015). Geleneksel ve tamamlayıcı tıp uygulamaları yönetmeliği ile Yönetmelik Taslağı'nın karşılaştırılması. Türkiye Biyoetik Dergisi, 2(2), 117-26.

Kaya, E., ve Altınbilek, T. (2019). Osteopati yaklaşımı; bel ve boyun ağrilarında yeri. Journal of Biotechnology and Strategic Health Research, 3, 85-90.

Kılıç, Y. (2014). Turizm sektörü istihdamının eğitim durumu ve insangücü planlaması. Eğitim Bilimleri Araştırmaları Dergisi, 4(1), 419-436.

Kökten, G. (2017). Bir üniversite hastanesinde polikliniğe başvuran cildiye hastalarında tamamlayıcı ve alternatif tıp yöntemlerinin kullanımı. Yüksek Lisans Tezi, Harran Üniversitesi Sağlık Bilimleri Enstitüsü, Şanlıurfa.

Lindquist, R., Tracy, M. F., ve Snyder, M. (Eds.). (2013). Complementary \& alternative therapies in nursing. (Seventh Edition), Springer Publishing Company.

Magretta, J. (2012). Understanding michael porter. the essential guide to competition and strategy. Boston, MA, ABD: Harvard Business Review Press.

McKay, A., ve M Wangchuk, D. (2018). Traditional medicine in Bhutan. Asian Medicine, 1(1), 204-218.

Mollahaliloğlu, S., Uğurlu, F. G., Kalaycı, M., ve Öztaş, D. (2015). Geleneksel ve tamamlayıcı tıp uygulamalarında yeni dönem. Ankara Medical Journal, 15(2).

Neven, D., ve Droge, C.L.M., (2001). A diamond for the poor? assessing Porter's Diamond Model for the analysis of agro-food clusters in the developing countries, proceedings of the 11th annual world food and agribusiness forum and symposium, 25-28 June, Australia.

Özgök, A. (2013). Hipnoz ve anestezi. Anestezi Dergisi, 21(1), 11-16.

Özler, M., Öter, Ş., ve Korkmaz, A. (2009). Ozon gazının tıbbi amaçlı kullanılması. TAF Preventive Medicine Bulletin, 8(1).

Özmen, S., Demir, H. Y., Yavuzer, R., ve Atabay, K. (2005). Alternatif estetik uygulamalar-1: mezoterapi. Türk Plastik, Rekonstrüktif ve Estetik Cerrahi Dergisi, 13(3), 195-201.

Öztürk, O., ve Selçuk, M. Y. (2016). Apitherapy in primary care. Turkish Journal of Family Medicine and Primary Care, 10(3), 124-125.

Pal, S. K. (2002). Complementary and alternative medicine: an overview. Current Science-Bangalore-, 82(5), 518-524. 
Park, Y. L., Huang, C. W., Sasaki, Y., Ko, Y., Park, S., ve Ko, S. G. (2016). Comparative study on the education system of traditional medicine in China, Japan, Korea, and Taiwan. Explore, 12(5), 375-383.

Porter, M. E. (1989). How competitive forces shape strategy. In Readings in Strategic Management, (pp. 133-143).

Porter, M. E. (1991). Towards a dynamic theory of strategy. Strategic Management Journal, 12(S2), 95-117.

Porter, M. E. (1998). Clusters and the new economics of competition. Boston, MA: Harvard Business School Press, 76(6), 77-90.

Porter, M. E., ve Van der Linde, C. (1995). Toward a new conception of the environment-competitiveness relationship. Journal of Economic Perspectives, 9(4), 97-118.

Porter, M.E. (1990). The competitive advantage of nations. The MacMillan Press Ltd., London and Basingstoke, 1(1), 70-91.

Rabago, D., Slattengren, A., ve Zgierska, A. (2010). Prolotherapy in primary care practice. Primary Care: Clinics in Office Practice, 37(1), 65-80.

Rao, N. J., Subash, K. R., ve Kumar, K. S. (2012). Role of phytotherapy in gingivitis: a review. Int $J$ Pharmacol, 1, 1-5.

Riasi, A. (2015). Competitive advantages of shadow banking industry: an analysis using Porter Diamond Model. Business Management and Strategy, 6(2), $15-27$.

S.B. (T.C. Sağlık Baakanlı̆̆ı). (2019). 2. Uluslararası geleneksel ve tamamlayıcı tıp kongresi özet kitabı. 2019, Ankara.

Sar1, D. (2016). Gaziantep ili Ŏguzeli ilçe merkezinde 18 yaş ve üstü erişkinlerde biyolojik ve alternatif/ tamamlayıcı tıbbi tedavi kullanma durumu ve etkileyen faktörler. Uzmanlık Tezi, Gaziantep Üniversitesi Tıp Fakültesi, Gaziantep.

Schwenger, D., Straub, T., ve Borzillo, S. (2014). Non-governmental organizations: strategic management for a competitive world. Journal of Business Strategy, 35(4), 11-19.

Selli, F., Eraslan, İ. H., Chowdhury, D., ve Sukumar, A. (2010). International competitiveness: analysis of Turkish animal husbandry: an empirical study in GAP region. Enterprise Risk Management, 2(1), 100-114.

Singh, V., Raidoo, D. M., ve Harries, C. S. (2004). The prevalence, patterns of usage and people's attitude towards complementary and alternative medicine (CAM) among the Indian community in Chatsworth, South Africa. BMC Complementary and Alternative Medicine, 4(1), 3. 
Somer, P., ve Vatanoğlu, E.E. (2017). Geleneksel ve Tamamlayıcı Tıp Uygulamaları Yönetmeliği'nin hukuki ve etik açıdan değerlendirilmesi. Anadolu Kliniği, 22(1). 58-65.

Suci, M. (2015). Türk savunma sanayiinin sürdürülebilir rekabet avantajina ulaşmasında talep koşullarının etkisi ve önemi. Yüksek Lisans Tezi, Harp Akademileri Stratejik Araştırmalar Enstitüsü. İstanbul.

Şahin, S. (2017). Geleneksel, tamamlayıcı, alternatif tıp uygulamalarına genel bir bakış. Türkiye Aile Hekimliği Dergisi, 21(4), 159-162.

Şarışen, Ö., ve Çalışkan, D. (2005). Fitoterapi: bitkilerle tedaviye dikkat (!). Sted, 14(8), 182-187.

T.C. Resmî Gazete- 1. Akupunktur tedavi yönetmeliği, Resmî Gazete Say1 No:20885 (29.05.1991).

T.C. Resmî Gazete- 2. Akupunktur tedavisi uygulanan özel sağlık kuruluşları ile bu tedavinin uygulanması hakkında yönetmelik, Resmî Gazete Sayı No:24879 (17.09.2002). https://www.resmigazete.gov.tr/eskiler/2002/09/20020917.htm, (Erişim Tarihi: 07.01.2020)

Tanyüksel, M., Koru, Ö., Araz, E., Kılbaş, H. Z. G., Yıldız, Ş., ve Alaca, R. (2014). Kronik yaraların tedavisinde steril lucilia sericata larva uygulamaları. Gulhane Med J, 56(4), 218-22.

Tekiner, H. (2019). Kronik hastalıklarda geleneksel ve tamamlayıc1 tıp uygulamalarının tarihsel kaynağı olarak tıp yazmalarının kullanımı: mevcut durum ve gelecek. 2. Uluslararası Geleneksel ve Tamamlayıcı Tip Kongresi. (54-55). Ankara: Sağlık Bakanlığı.

Thomson, P., Jones, J., Evans, J. M., ve Leslie, S. L. (2012). Factors influencing the use of complementary and alternative medicine and whether patients inform their primary care physician. Complementary Therapies in Medicine, 20(1-2), 45-53.

Timurçin, D. (2010). Türkiye'de KOBI'lerin rekabet gücü ve rekabet üstünlüğü sağlamada kümelenmenin etkisi. Doktora Tezi, İstanbul Üniversitesi Sosyal Bilimler Enstitüsü, İstanbul.

Toksar1, M., Mürütsoy, M., ve Bayraktar, M. (2014). Tüketici algılarını etkileyen faktörlerde sosyal medyanın rolü: Niğde Üniversitesi İiBF örneği. Uşak Üniversitesi Sosyal Bilimler Dergisi, 20(20), 1-28.

Tolunay, A., ve Akyol, A. (2006). Kalkınma ve kırsal kalkınma: temel kavramlar ve tanımlar. Türkiye Ormancıllk Dergisi, 7(2), 116-127.

TTB (Türk Tabipler Birliği). (2017). Tıbbın alternatifi olmaz! geleneksel alternatif ve tamamlayıcı tıp uygulamaları. (Hazırlayan: Serpil Tütüncü ve Nilay Etiler). Ankara. 
TTB (Türk Tabipler Birliği). (2017). Tıbbın alternatifi olmaz! geleneksel alternatif ve tamamlayıcı tıp uygulamalart. (Hazırlayanlar: Serpil Tütüncü Nilay Etiler), Türk Tabipleri Birliği Halk Sağlığı Kolu, 7, Ankara Türk Tabipleri Birliği Yayınları.

Turan, N., Öztürk, A., ve Kaya, N. (2010). Hemşirelikte yeni bir sorumluluk alanı: tamamlayıcı terapi. Maltepe Üniversitesi Hemşirelik Bilim ve Sanatı Dergisi, 3(1), 93-8.

Tütüncü, S. ve Etiler, N. (2017). Tibbin alternatifi olmaz! geleneksel alternatif ve tamamlayıcı tıp uygulamalar. Ankara: Türk Tabipler Birliği Yayınları.

Uyar, M., ve Akın Korhan, E. (2011). Yoğun bakım hastalarında müzik terapinin ağr1 ve anksiyete üzerine etkisi. $A \breve{G R I, ~ 23(4): 139-146 . ~}$

Ünal, M., ve Dağdeviren, H. N. (2019). Geleneksel ve tamamlayıcı tıp yöntemleri. Fam Med, 8(1), 1-9.

WHO (The World Health Organization), (2020). Collaborating centres: WHO collaborating centres database \& portal. https://www.who.int/about/who-weare/structure/collaborating-centres, (Erişim Tarihi: 03.01.2020)

WHO (The World Health Organization). (2001). Legal status of traditional medicine and complementary/alternative medicine: a worldwide review. World Health Organization, Geneva.

WHO (The World Health Organization). (2005). Kayropraktikte temel eğitim ve güvenliği üzerine $W H O$ rehber kitapçı̆̆l. (Çeviri; Kayropraktik Derneği). Cenevre.

WHO (The World Health Organization). (2013). WHO traditional medicine strategy 2014- 2023. World Health Organization, Geneva.

WHO (The World Health Organization). (2019). WHO global report on traditional and complementary medicine. Luxembourg. Geneva.

Yüksel, A., ve Eraslan, İ. H., (2015). Kırsal kalkınma: genel yaklaşım ve havza yönetimi uygulamaları, Sage Yayıncılık. 